\title{
Chapter 1 \\ The Immigration-Emigration Nexus in Non-EU Sending States: A Focus on Welfare Entitlements, Consular Services, and Diaspora Policies
}

\author{
Daniela Vintila and Jean-Michel Lafleur
}

\subsection{Introduction}

In recent years, the topic of migrants' access to social protection has increasingly become an issue of concern amongst scholars, policy makers and citizens alike (Ruhs and Palme 2018). Yet, this interplay between migration and welfare has gained much more salience in some world regions than in others, being intensively discussed especially in the European Union (EU). The rising interest on how European welfare states adapt to international mobility is due to a combination of factors that points towards the peculiarity of this region. On the one hand, it can be seen as a direct effect of the accelerated migration inflows that EU countries have witnessed during the last decades, coupled with worrying levels of vulnerability faced by migrant populations, especially in times of economic crisis (Vintila and Lafleur 2020 in volume 1 of this series). On the other hand, the rising societal opposition towards migrants' access to welfare in Europe and the increasing politicisation of this topic in some EU destination countries (Lafleur and Stanek 2017; Ruhs and Palme 2018; Schmidt et al. 2018) have further contributed to the academic and political attention to the openness or closure of European social protection systems to mobile individuals.

Consequently, an extensive body of literature has examined how EU countries treat international migrants in terms of their access to welfare. Some pieces of work have focused exclusively on welfare-related dynamics among intra-EU migrants. In

\footnotetext{
D. Vintila $(\bowtie)$

Centre for Ethnic and Migration Studies (CEDEM), University of Liege, Liege, Belgium e-mail: Daniela.Vintila@uliege.be

J.-M. Lafleur

FRS-FNRS \& Centre for Ethnic and Migration Studies (CEDEM), University of Liege,

Liege, Belgium

e-mail: JM.Lafleur@uliege.be
} 
doing so, they aimed to examine the articulation between free movement and social policy in a context in which the EU's supranational legislation on non-discrimination and social security coordination has progressively facilitated mobile Europeans' access to welfare in their EU home and host countries (Martinsen 2005; Blauberger and Schmidt 2014; Kramer et al. 2018; Schmidt et al. 2018, among others). Additionally, recent studies have also paid attention to third-country nationals residing in the EU, a group that faces not only higher risk of poverty and social exclusion, but also more institutional barriers for accessing welfare benefits in EU destination countries (European Migration Network 2014; Lafleur and Vintila 2020a).

Despite these rich theoretical and empirical contributions regarding the interplay between mobility and welfare, the existing literature on this topic still faces major limitations. First, by mainly examining how the host country's welfare configuration treats international migrants, past studies have often neglected the fact that mobile individuals can also benefit from certain levels of social protection from their origin countries. The diaspora literature shows that home countries often develop a wide repertoire of policy initiatives to keep links with their nationals abroad (Agunias and Newland 2012; Collyer 2013; Ragazzi 2014; Delano 2018; Gamlen 2019). In some cases, this also covers specific policies and programs aiming to ensure the social protection of non-resident nationals, especially those facing strong economic hardship (Lafleur and Vintila 2020b). Second, in the attempt to measure migrants' access to welfare, past studies have mainly adopted a Eurocentric perspective by closely examining the real and anticipated consequences of human mobility on European social protection systems. However, the historical development and recent achievements of European welfare states make them a unique case study; and many socioeconomic and welfare-related dynamics witnessed across European democracies may not be easily generalizable worldwide. In fact, the way in which non-European welfare states respond to international mobility still stands out as a grey area in migration and social policy literature, as very few studies have focused on the nexus between migration and welfare beyond the EU context. Even when extending the scope of the analysis beyond the EU, most studies have rather explored informal strategies and practices of transnational social protection of non-EU migrants in European countries and their families left in the homeland, rather than systematically analysing how they access welfare benefits from origin countries (see Boccagni 2011; Sainsbury 2012; Merla and Baldassar 2011; Lafleur and Vivas Romero 2018).

This volume seeks to address this research gap by taking the perspective of nonEU countries on migrant social protection. In doing so, we address the following research questions: What type of social protection policies do non-EU sending countries adopt for their nationals abroad, including those residing in EU Member States? Do non-EU countries grant a differentiated access to social benefits for their emigrant populations when compared to foreign or national citizens residing in their territory? In other words, do non-EU states treat immigrants and emigrants differently when it comes to social protection? By providing an in-depth analysis of these questions, this volume thus complements the other two books included in this series (Lafleur and Vintila 2020a, b) that closely examine the interplay between migration and social protection in Europe and beyond. 
Our analysis focuses on a sample of 12 sending countries for migrants residing in the EU (Argentina, China, Ecuador, India, Lebanon, Morocco, Senegal, Serbia, Switzerland, the Russian Federation, Tunisia, and Turkey), plus the United Kingdom (UK) after the Brexit referendum. This sample of 12 non-EU countries is particularly relevant for our purposes for several reasons. To begin with, these countries are distributed across different world regions (first step of our case selection process) and they count with a population of more than three million individuals (second step, aiming to exclude from the analysis very small states which may put forward rather distinctive social policy and migration patterns). These countries also have significant shares of nationals abroad (their diaspora worldwide accounts for more than $1 \%$ of their total population- third step) and a substantial segment of their diaspora (more than $40 \%$ ) resides in the EU (fourth step). Their diaspora has a significant presence across several EU Member States, by being in the top five foreign nationalities in at least two EU countries (fifth step). Finally, these 12 countries are stable states (with a score of 10 or less in the 2016 State Fragility Index and Matrix- sixth step), ${ }^{1}$ while also counting with sufficient variation in the historical development of their welfare regimes (seventh selection criterion). The United Kingdom that was, until recently, an EU Member State, was added to this volume as it represents a quite peculiar case. Just like other countries analysed in this book, the UK counts with a significant diaspora abroad, although a smaller share of its non-resident population (around 25\%) lives in EU countries. Nevertheless, UK citizens are in the top five foreign nationalities residing in more than a half of current EU Member States (Lafleur and Vintila 2020c); and interesting changes in access to social protection of the UK diaspora in the EU and of EU citizens in the UK are likely to occur in the future.

Two chapters are dedicated in this volume to each one of these 13 countries. For each country, the first chapter focuses on access to social benefits across five core policy areas (health care, unemployment, old-age pensions, family benefits, guaranteed minimum resources) by highlighting the type of social protection policies offered to national residents, non-national residents, and non-resident nationals. For each policy area, we look at a rather broad array of social benefits including: benefits in kind and cash in case of sickness, invalidity benefits, unemployment insurance and assistance benefits, contributory and non-contributory old-age pensions, maternity, paternity, parental and child benefits, and social assistance programs (see Vintila and Lafleur 2020 for a more detailed description of these benefits). The second chapter for each case study discusses the role of three key actors (consulates, diaspora institutions, and home country ministries/agencies responsible for specific social policy areas) through which non-EU countries interact with their nationals abroad across the five policy areas previously mentioned (see further details in Lafleur and Vintila 2020c).

\footnotetext{
${ }^{1}$ This index was developed by the Integrated Network for Social Conflict and Research (INSCR) and it covers all independent countries in the world with a population of more than 500,000 in 2016. For each country, the fragility score takes into account aspects related to effectiveness and legitimacy across four performance dimensions: security, political, economic and social. See: https://www.systemicpeace.org/inscrdata.html. Accessed 16 March 2020.
} 
For each country, the data for both chapters are based on two surveys with national experts (one survey for the first chapter on access to social protection and another survey for the second chapter on diaspora policies and institutions). The surveys were conducted in the framework of the ERC-funded project "Migration and Transnational Social Protection in (Post) Crisis Europe" (MiTSoPro); ${ }^{2}$ and they included standardised questions to ensure the comparability of our findings across countries counting with different welfare and migration features. For each survey (see details in the introductory chapters of volumes 1 and 2 in this series), national experts were asked to provide objective information regarding the eligibility conditions for accessing social benefits (first survey) and diaspora policies and initiatives for nationals abroad (second survey).

\subsection{Social Policy Developments in Non-EU Contexts}

Broadly speaking, the development of welfare and social policies in non-European contexts has historically followed a quite different path when compared to the EU (for an overview of EU countries, see Lafleur and Vintila 2020a). This has attracted an increasing scholarly interest on how non-European welfare regimes have the potential to challenge or redefine different typologies of ideal social policy models that have emerged after the seminal work of Esping-Andersen (1990) on the Three Worlds of Welfare Capitalism (see Ferrera 1996; Bonoli 1997; Österman et al. 2019, among others). However, the variation across non-EU social protection schemes - sometimes closely linked to very distinctive historical, economic, political or societal traits than the ones observed in the EU- makes their categorization into existing "ideal" social policy models rather difficult (see Rudra 2007 or Mkandawire 2016 for more detailed discussions on how existing typologies overlook varieties of welfare capitalism in developing countries). This is particularly the case considering that "one size fits all" typologies strongly clash not only with the diversity of welfare institutions and provisions between different regions around the globe, but also with increasing cross-country differences even within the geographical boundaries of the same world region.

Currently, there are still major differences across non-EU countries between those counting with rather generous welfare regimes (mostly present in wealthier high-income states) and the welfare state of developing countries that often remains hybrid, heavily fragmented and relatively fragile. The latter is observable especially across countries in more volatile economic contexts with significant macro-economic imbalances in which specific benefits rather generalised across EU welfare states either do not exist or have been replaced by different (often less institutionalised)

\footnotetext{
${ }^{2}$ http://labos.ulg.ac.be/socialprotection/. Accessed 16 March 2020. The survey was conducted between April 2018-January 2019 and several rounds of consistency check were centrally conducted by the MiTSoPro team. Given the period in which the survey was conducted, the country chapters included in this volume focus mainly on the policies in place at the beginning of 2019.
} 
social protection initiatives. In many of these countries (including several of the countries analysed in this volume), the development of welfare institutions and provisions has often encountered similar socio-economic challenges, including rising levels of poverty and increasing income and class-related disparities. As we will explain in this book, policy makers have sometimes attempted to address these challenges via processes of policy diffusion or, more broadly, policy convergence, with some countries implementing welfare schemes previously institutionalised in other contexts, by adapting them to the specificities of domestic receiving environments.

By way of example, Barrientos (2009) argues that until the 1980s, the development of welfare institutions in Latin America was largely influenced by the conservative welfare regime of several European countries, particularly when it comes to the support offered to families in protecting male breadwinners via occupationally stratified insurance schemes. However, unlike their European counterparts, Latin American welfare regimes restricted the level of protection and insurance only for workers engaged in formal employment. Given this distinguishable peculiarity, until the 1980s, the Latin American welfare state was considered as rather hybrid or conservative-informal (see also Carmona Barrenechea et al. this volume). Nevertheless, as Barrientos (2009) points out, recent reforms shifted this paradigm towards a "liberal-informal" social policy model operating in a context of increasing unemployment rates, poverty and income inequalities in the region. Additionally, in response to poverty reduction targets, new social assistance programs have recently emerged, thus introducing new forms of protection disconnected from the labour market. Yet, these similar social policy influences or developments did not automatically lead to a harmonization of welfare regimes across Latin American states, as significant cross-country variations still exist (Riesco 2009). Franzoni (2008) mapped out 18 Latin American countries into three main clusters of welfare regimes, showing that the two Latin American states analysed in this volume respond to quite different social policy features. On the one side, Argentina shows higher decommodification, stronger formalisation of labour and income levels, higher public expenditure and a system targeting the poor, with many of these features being also present in other Latin American cases, such as Chile. On the other hand, Ecuador (together with Colombia, Peru or Guatemala, among others) has been characterised for a long time by low decommodification of the labour force, limited levels of occupied salaried workers, limited Gross Domestic Product (GDP) per capita, low social policy expenditure and a largely informal labour market in which families play a significant role for risk management. As also discussed in this volume, Ecuador reshaped its domestic social policy since 2007, with the consolidation of labour protection and a series of executive decrees aiming to secure immediate investments for education and health care, thus shifting towards a more universal model.

Certain welfare-related similarities and European-driven influences can also be found across other countries in the Global South. In many of them, the development of welfare arrangements has been shaped after social protection schemes already operating across European countries, often as a direct consequence of colonial interference or more indirect colonial legacies, in general. India received strong colonial influences in the development of its welfare regime, with many of its current social 
security arrangements and labour regulations being influenced by the country's colonial past. Although the country has experienced strong economic growth and managed to reduce the ratio of people living in extreme poverty, ${ }^{3}$ social inequality and uneven access to social protection persist. As highlighted in this volume, the Indian welfare system remains highly fragmented, with formal workers receiving more generous social security arrangements following the colonial legacy; and a large share of the labour force working in the informal sector without access to social security schemes.

On the other hand, countries from the Middle East and North Africa, such as Morocco or Tunisia, have witnessed for a long time populist state welfare provisions in which the state provided for its citizens in return for their loyalty to the regime (Harrigan and El-Said 2014). The first modern type of social security schemes emerged in Tunisia when the country was under the French protectorate, but significant reforms have been implemented after the independence (Gelb and Marouani this volume). These reforms led to substantial progress in terms of strengthening state's role in social provisioning with high social spending, a development of social security institutions, and the adoption of new social protection schemes for the unemployed and the poor (Cheikh 2013; Harrigan and El-Said 2014). Yet, economic growth and high employment rates continue to be concentrated in specific areas only (Amara and Ayadi 2013); and informal economy - together with limited social coverage mainly affecting low-income and vulnerable individuals - remains a top priority to be addressed via structural policy reforms (Cheikh 2013). As explained in this book, Morocco also maintains some welfare arrangements and institutions strongly influenced by its past as French protectorate. One of the main challenges faced by the Moroccan welfare state is the inadequacy of its social assistance program for the most vulnerable, despite recent reforms incentivized by the International Monetary Fund and the World Bank, aiming to reduce the poverty rate (Harrigan and El-Said 2014). The situation is even more complicated in Senegal. This country has been characterised as a "cash crop economy" (Mkandawire 2016) in which social protection is often informal and community-based, with limited public spending on welfare. As shown in this volume, the Senegalese welfare system is actually a legacy from France, with its first pillars being established long before the 1960 independence.

Certain social policy developments strongly influenced by the EU or with significant similarities with other European welfare states can also be observed in Turkey, Switzerland, and the UK. The Europeanisation process has strongly affected the development of social policy arrangements in Turkey. As highlighted in this book, the country has witnessed significant welfare reforms, especially since the mid-2000s. In light of these changes (including the attempts to implement a single pension system, the adoption of a universal health insurance, the unification of social security institutions or the restructuring of social assistance programs), Aybars and Tsarouhas (2010) evaluate the Turkish social policy model as a rather

\footnotetext{
${ }^{3}$ See: https://www.worldbank.org/en/country/india/overview. Accessed 16 March 2020.
} 
hybrid one. They argue that Turkey combines important elements of the Middle Eastern welfare regime (with religion playing a significant role and social policies following more the idea of nation-building, rather than the one of social citizenship rights) and the South European one (with low social expenditure, strong reliance on families for welfare provision, and fragmented welfare delivery). On the other hand, the well-developed Swiss and UK welfare regimes share significant social policy traits with EU Member States. The Anglo-Saxon welfare regime in the UK is usually defined by weak universalism, free health care services, and social benefits for individuals in need in which means-testing plays a significant role. Many of these social policy features can also be observed in Ireland and, to a lesser extent, in Malta (Vintila and Lafleur 2020). In turn, Switzerland, unlike other European countries, implemented social insurance programs relatively late (Trampusch 2010). Until the 1970s, the Swiss welfare regime was considered as a liberal one, although subsequent reforms shifted the country towards a conservative and continental welfare state that still preserves important features of a liberal social policy model (Armingeon 2001).

The rest of the countries analysed in this volume also put forward significant diversity in the development and main rationale of their welfare systems. Russia - which has witnessed strong economic performance and recent social policy reforms aiming to introduce residual, neo-liberal welfare arrangements- has been categorised by Cerami (2009) as an oil-led welfare state in which high oil and gas prices have significantly shaped the contemporary social protection system. Most of the welfare-related reforms implemented since 1989 targeted the privatisation of provisions, management decentralisation, strengthening the social insurance principle and the implementation of a residual unemployment protection scheme coupled with basic safety nets (Cook 2000; Cerami 2009). China has also experienced impressive economic growth since the market-oriented reforms initiated in the 1980s, up to the point that today, it represents the second largest world economy. This economic performance is reflected in indicators such as the increase of the GDP or workers' wages. Yet, significant challenges including regional and class disparities or strong inequalities in accessing basic education or health care (especially in rural areas) remain to be addressed (London 2014; He this volume).

Finally, Serbia and Lebanon also respond to rather distinct social policy models. Social policy development in Serbia has been strongly influenced by the legacy of the communist welfare regime. The post-communist Serbian welfare system has been characterized by reduced social spending during the transition, high share of private sources in health care, low social assistance coverage and high number of pension beneficiaries, with facilitated early retirement aiming to solve increasing unemployment rates (Stambolieva 2013). As shown in the country chapters in this volume, most attempts to reform the Serbian welfare system took place especially since the 2000s, although some of them were rather unsuccessful. As for Lebanon, the development of its welfare regime highlights the importance of non-state actors (religious charities, sectarian parties) in a context of fragile state-related welfare institutions, fragmented social protection schemes, minimal public provisions and 
increasing socio-economic challenges of human impoverishment (Jawad 2002; Cammett and Issar 2010; Tabar et al. this volume).

This diversity in social policy developments across the 13 countries included in our sample is also reflected in their varying levels of social protection expenditure (Table 1.1) and effective coverage (Table 1.2). As shown in Table 1.1, total social protection expenditure as share of the GDP still varies widely across these countries, with some of them (India, Lebanon, Senegal) allocating 5\% or less on social protection. This is in clear contrast with countries such as Serbia, Switzerland, the UK or the Russian Federation in which social protection expenditure accounts for more than $15 \%$ of the GDP. By type of schemes, the expenditure ratio is generally higher for older persons. For instance, Argentina, Russia, Serbia or Turkey spend $8 \%$ or more of their GDP for the protection of the elderly, whereas the resources dedicated to this group in Senegal, Ecuador, Lebanon, China or Morocco are much lower. Public expenditure for children or individuals in active age (including expenditure for unemployment, labour market programs, sickness-related benefits or social assistance) is usually more reduced than for old-age; and generally higher in Serbia, Argentina, Switzerland, the UK, and Russia. Across these 13 countries, public expenditure is extremely limited especially for sickness and maternity $(0.3 \%$ of the GDP or less in India, Senegal, Turkey, Ecuador) and general social assistance ( $0.3 \%$ or less in Morocco, Senegal, Ecuador, China, Turkey).

In any case, a higher allocation of public resources for specific groups does not necessarily mean that these groups are well secured against vulnerability or social risks, as social protection expenditure may still be insufficient to cover a large number of persons in need. Table 1.2 compares the social protection effective coverage across the selected countries. India and Ecuador report a very limited effective coverage, especially when compared to Switzerland, the UK or Russia. By specific groups, effective coverage tends to be higher for older persons (except for Senegal, Lebanon, India, Turkey, Morocco or Tunisia) and children (except for China or Senegal, from the countries for which the data is available), when compared to unemployed or other vulnerable groups.

As discussed in several chapters in this book, this rather limited social protection coverage, especially for individuals in working age, is often linked to high levels of informal employment. This structural problem of informality has serious implications on (national and foreign) workers' formal access to welfare. Informal employment reaches very high rates especially in Senegal, India, and Morocco, where informality is $80 \%$ or more of employment (Fig. 1.1). Thus, very limited segments of the population of these countries can actually benefit from social protection policies linked to formal employment status. Ecuador, Tunisia, China, and Argentina also return very high shares (more than $40 \%$ ) of informal employment, thus also excluding significant proportions of the population from employment-based welfare entitlements. Informal employment is much more limited in Serbia, Switzerland, and the UK. Turkey returns the highest difference by gender, with the share of female workers in informal employment being much higher when compared to their male counterparts. 


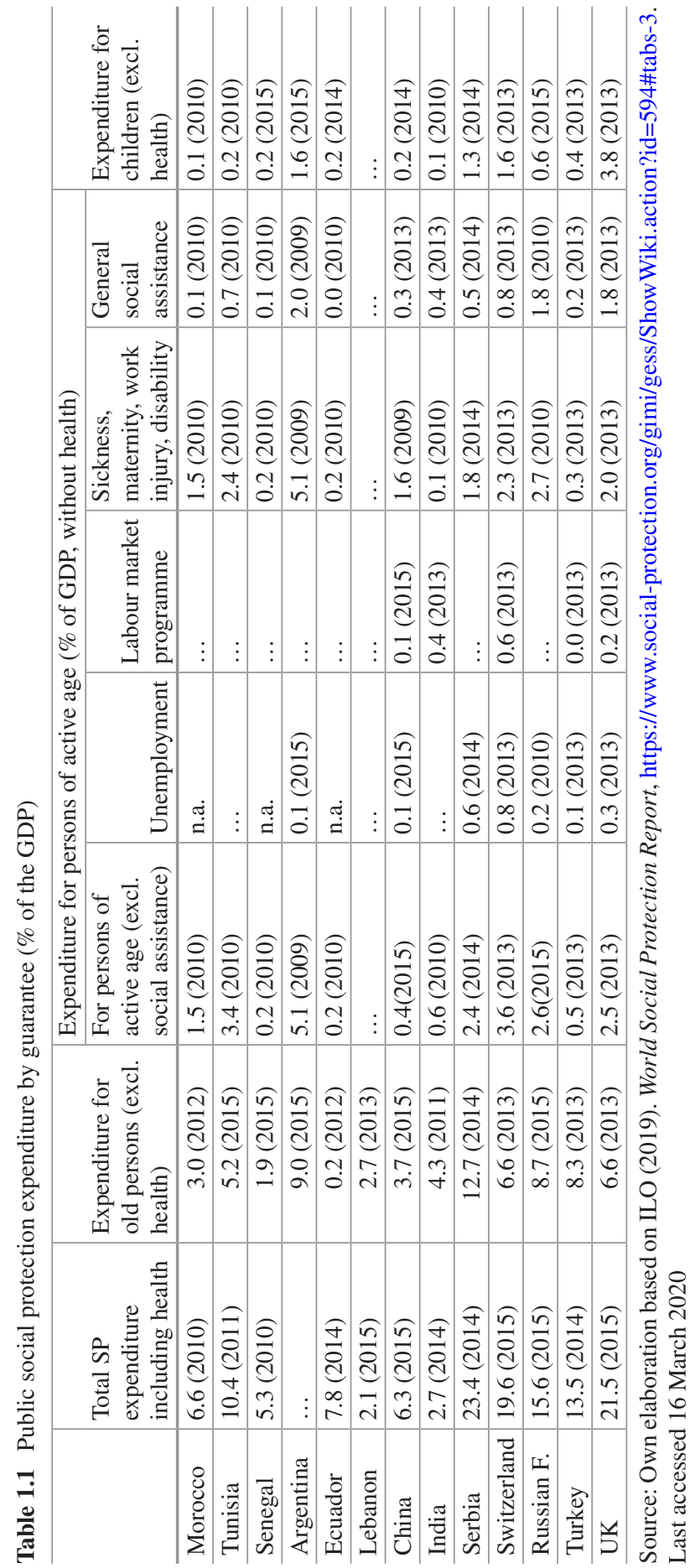




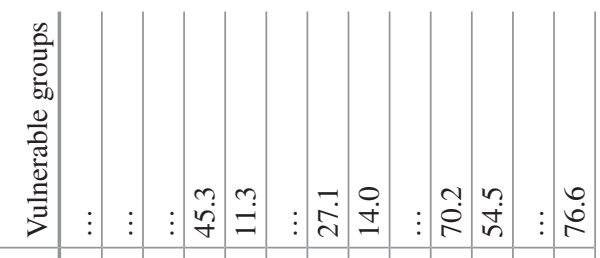

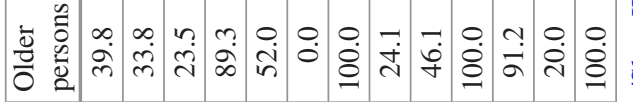
उ

을

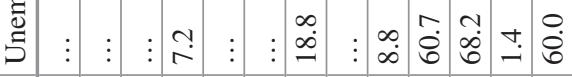

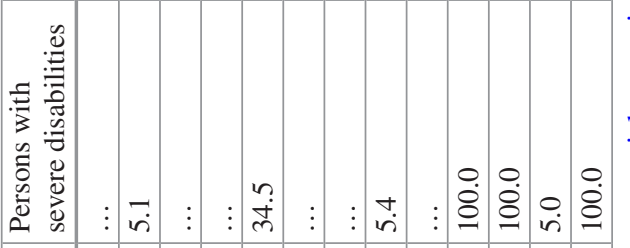

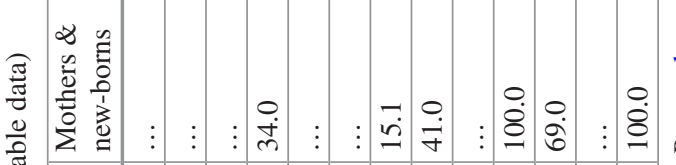

莺

总

$\frac{\overline{0}}{3}$

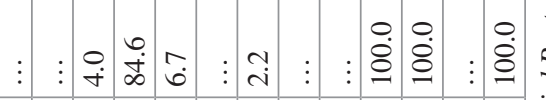

章

言

$\frac{\vec{a}}{\frac{\pi}{5}}$

s.

एक

家

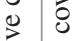

突

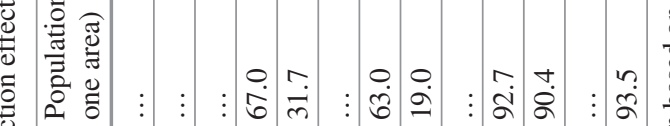

ํํㄹ

$\frac{2}{8}$

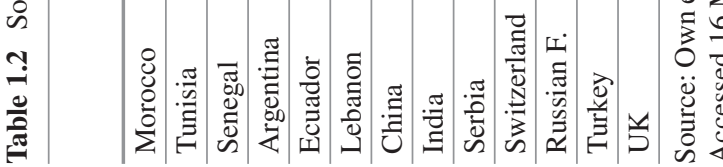




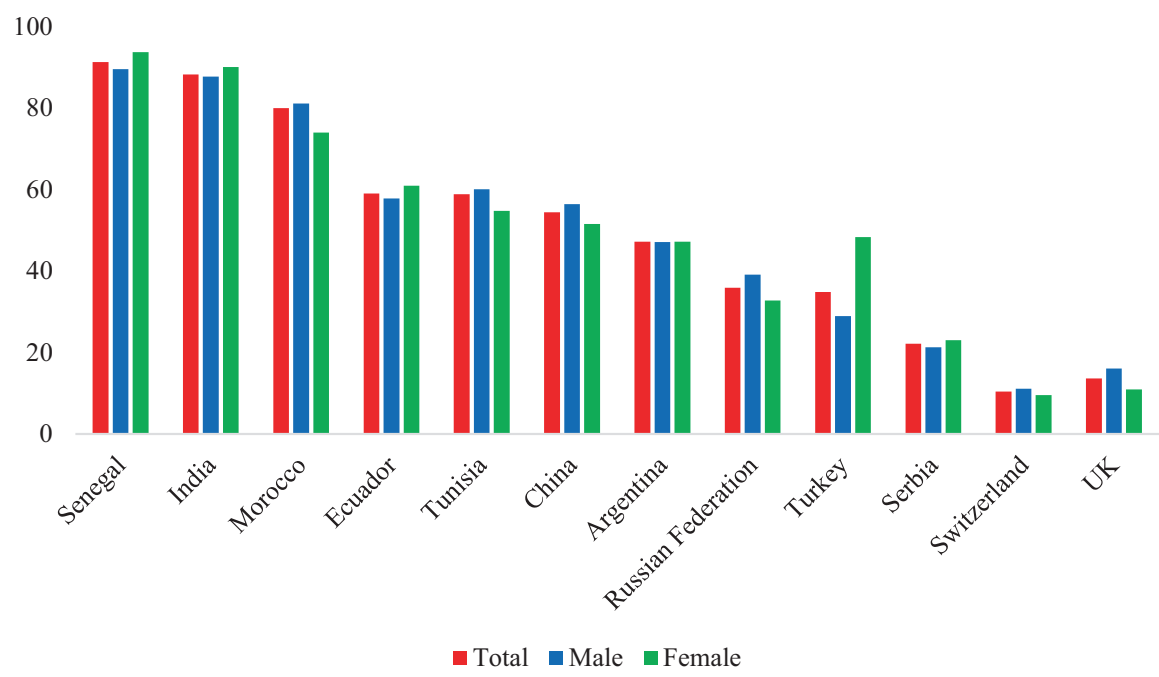

Fig. 1.1 Share of informal employment in total employment (\%), by gender. (Source: Own elaboration based on ILO (2018). Women and men in informal economy. A statistical picture (third edition), https://www.ilo.org/global/publications/books/WCMS_626831/lang\%2D\%2Den/index. $\mathrm{htm}$. Accessed 16 March 2020. The data for Lebanon is not available)

Apart from their welfare and labour market characteristics, the countries analysed in this book also vary widely in the Human Development Index ranking (HDI, Table 1.3) and poverty levels (Fig. 1.2). Switzerland, the UK, Argentina, and Russia score quite high in the Human Development Index. Unsurprisingly, Switzerland returns a very high gross income per capita and higher life expectancy and years of schooling than any other country analysed here. Turkey, Serbia, Lebanon, Ecuador, China, and Tunisia also rank high in this index (top 100), although their gross national income is substantially smaller when compared to Switzerland, the Russian Federation, the UK or Argentina. Finally, Morocco and India report only a medium human development score, whereas Senegal occupies the last position in this rank among the 13 selected countries.

Important variations are also observable when looking at the evolution of the poverty headcount ratio at national poverty lines (as percentage of the population) across these countries (Fig. 1.2). In general, the share of those living below poverty lines has significantly decreased over time across all countries analysed, but especially so in India, Tunisia, Russia or China, due to reforms adopted during the past years. Yet, the poverty headcount ratio still reaches worrying levels especially in Senegal and Lebanon (46\% and 27\% respectively in 2012), but also in Argentina, Serbia, Ecuador or India (more than $20 \%$ in each case). On the other hand, both 
60

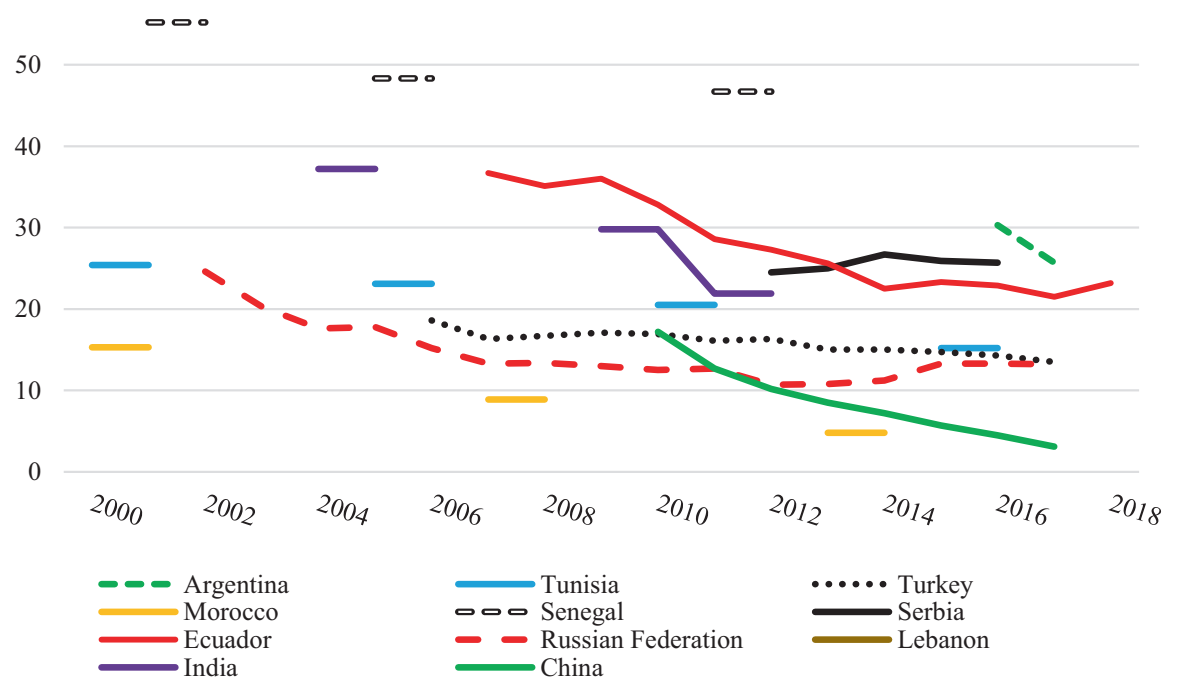

Fig. 1.2 Poverty headcount ratio at national poverty lines (\% of population), 2000-2018. (Source: Own elaboration based on the data from the Global Poverty Working Group of the World Bank (https://data.worldbank.org/indicator/SI.POV.NAHC, accessed 16 March 2020). The figures for Switzerland and the UK are not available. The data for Tunisia, Morocco, Senegal, and India are available only for specific non-consecutive years, but the dots are connected for consecutive years only for illustration purposes)

Table 1.3 Selected non-EU countries by Human Development Index

\begin{tabular}{|c|c|c|c|c|c|c|}
\hline & $\begin{array}{l}\text { Human } \\
\text { Development } \\
\text { Index (HDI) }\end{array}$ & $\begin{array}{l}\text { Life } \\
\text { expectancy } \\
\text { at birth }\end{array}$ & $\begin{array}{l}\text { Mean years } \\
\text { of } \\
\text { schooling }\end{array}$ & $\begin{array}{l}\text { Gross } \\
\text { national } \\
\text { income } \\
\text { (GNI) per } \\
\text { capita }\end{array}$ & $\begin{array}{l}\text { HDI } \\
\text { rank }\end{array}$ & $\begin{array}{l}\text { Human } \\
\text { development }\end{array}$ \\
\hline Switzerland & 0.944 & 83.5 & 13.4 & 57,625 & 2 & Very high \\
\hline UK & 0.922 & 81.7 & 12.9 & 39,116 & 14 & Very high \\
\hline Argentina & 0.825 & 76.7 & 9.9 & 18,461 & 47 & Very high \\
\hline $\begin{array}{l}\text { Russian } \\
\text { Federation }\end{array}$ & 0.816 & 71.2 & 12.0 & 24,233 & 49 & Very high \\
\hline Turkey & 0.791 & 76.0 & 8.0 & 24,804 & 65 & High \\
\hline Serbia & 0.787 & 75.3 & 11.1 & 13,019 & 66 & High \\
\hline Lebanon & 0.757 & 79.8 & 8.7 & 13,378 & 82 & High \\
\hline Ecuador & 0.752 & 76.6 & 8.7 & 10,347 & 84 & High \\
\hline China & 0.752 & 76.4 & 7.8 & 15,270 & 86 & High \\
\hline Tunisia & 0.735 & 75.9 & 7.2 & 10,275 & 96 & High \\
\hline Morocco & 0.667 & 76.1 & 5.5 & 7340 & 122 & Medium \\
\hline India & 0.640 & 68.8 & 6.4 & 6353 & 129 & Medium \\
\hline Senegal & 0.505 & 67.5 & 3.0 & 2384 & 165 & Low \\
\hline
\end{tabular}

Source: Own elaboration based on the Human Index Development of the United Nations Development Programme, http://hdr.undp.org/en/composite/HDI. Accessed 16 March 2020 
Morocco and China have reduced their poverty headcount ratio at less than 5\% according to the latest data available in each case. ${ }^{4}$

Finally, it is also worth mentioning that certain types of benefits rather generalised across EU countries (Vintila and Lafleur 2020) have not yet been implemented in some non-EU states (see also Fig. 1.7 in Sect. 1.4 of this chapter). An evident example is in the area of guaranteed minimum resources. Most countries examined here (Argentina, Ecuador, India, Lebanon, Senegal, Morocco, Tunisia or Russia) have not adopted yet general (non-categorical) social assistance schemes for the most vulnerable, although some of them do offer categorical social assistance programs for specific groups such as children or the elderly. Similar examples can be found in the area of unemployment or family benefits. As discussed by Dioh (this volume), Senegal (which also returns the highest share of informal employment) has not adopted yet any formal mechanism to deal with the risk of job loss. Lebanon also lacks a formal unemployment insurance or assistance scheme, the only provision available being an end-of-service benefit for those affiliated to the social security system. In the area of family benefits, although all these countries offer maternity benefits for female employees, some of them have not implemented yet specific paternity benefits schemes, whereas parental benefits exist as such only in few cases such as Serbia or Russia. Moreover, not all these countries offer child benefits (see the chapters on China, India or Turkey); and in some of them, these benefits are not granted to all families with children (as it is often the case in the EU), but only to the most vulnerable ones. As an illustration, the Human Development Bonus in Ecuador is granted only to heads of families with children under the age of 18 who live in conditions of extreme poverty.

Secondly, as mentioned before, some of these countries have recently adopted important social policy reforms with certain benefits being introduced only in the last years. Argentina adopted its unemployment insurance scheme in 1991, the Universal Child Allowance in 2008 and it renationalised the pension system in 2008. A social assistance scheme aiming to provide a safety net for the poor was introduced in China only in 1999 for the urban areas and in 2004 for the rural parts of the country. Similarly, India introduced its unemployment scheme in 2005, Ecuador did so in 2016, whereas Turkey experienced an important social security reform in 2006.

Thirdly, and even more importantly, despite recent attempts to introduce new social policy reforms, many of these countries still face major challenges to ensure individuals' access to social protection, regardless of their nationality. As explained in the chapters, some states still put forward very stratified social protection regimes that protect only those formally affiliated to the social security system via employment or voluntary contributions. While employment is a crucial element for

\footnotetext{
${ }^{4}$ The data on the evolution of the poverty headcount ratio at national poverty lines is not available for the UK and Switzerland. However, Eurostat data shows that in 2018, 17.4\% of individuals residing in Switzerland and $23.1 \%$ of those residing in the UK were considered at risk of poverty and social exclusion (compared to $21.6 \%$ for EU27). See: https://ec.europa.eu/eurostat/databrowser/view/sdg_01_10/default/table?lang=en. Accessed 16 March 2020.
} 
accessing welfare in many countries (including EU Member States, as shown by Vintila and Lafleur 2020), this condition becomes highly problematic in certain non-EU contexts in which the informal economy has a considerable weight. As discussed, many of the countries analysed here return very high proportions of informal workers. Since inclusion in social protection schemes derives from formal employment, this directly excludes high proportions of the population- nationals and foreigners alike- from accessing welfare. Consequently, even when specific welfare schemes exist- such as the ones for unemployment or old-age pensions-, informal workers are a priori excluded given their lack of contributions; and the pool of potential beneficiaries of these programs implicitly becomes quite limited. As in more than a half of the countries analysed here up to $40 \%$ of the labour force is engaged in informal employment, this leads to a significant exclusion of both national and foreign residents from accessing formal programs to protect them against specific risks. Additionally, even when employment or prior contribution requirements are met, the benefit levels are sometimes too limited to ensure an effective protection. As discussed by He (this volume), the amount received for unemployment benefits in China is so low that it does not guarantee an adequate protection of those who lose their jobs. Similarly, the chapter of Popova (this volume) on the Russian case shows that, despite the fact that government transfers cover a rather large segment of the population, most cash benefits do not actually reach the subsistence level, the adequacy of the coverage offered by these programs thus remaining quite limited.

Overall, this differentiated institutionalization and development of the welfare regimes of the 13 countries analysed here could significantly shape their responsiveness to the inclusion of immigrant or diaspora populations in their national social protection systems. Countries counting with limited resources and fragile welfare arrangements face considerable difficulties to ensure a sufficient and efficient coverage of the socio-economic needs of their resident nationals. Given these high pressures that already exist on their domestic welfare systems, the social protection of migrants may not be a top national priority, especially when compared to the much larger group of national residents in need. On the other hand, having a more generous and well-developed welfare regime is not necessarily expected to act as a guarantee that a country would be more inclined to ensure migrants' social protection. More developed welfare states may actually adopt a rather protectionist approach in trying to limit the number of beneficiaries potentially entitled to claim generous social benefits. 


\subsection{Non-EU Welfare States and the Immigration-Emigration Nexus}

As noted by Adamson and Tsourapas (2019), migration studies have often looked at the development of migration policies in the Global South by using analytical frameworks designed to understand migration regimes in the Global North. Consequently, migration policies of advanced economies such as EU Member States tend to be depicted primarily as guided by their role of immigrant receiving areas, while states in the Global South are mostly perceived as countries whose migration policies exclusively ought to deal with departure and transit. In volume 2 of this series (Lafleur and Vintila 2020b), we questioned this representation by showing how EU Member States also engage with citizens abroad in the area of welfare and beyond. Similarly, this volume discusses the case of non-EU countries that - while they represent important sending states of migrants coming to the EU- are also frequently receiving immigrants. In other words, the articulation between the engagement of non-EU sending states with their diaspora and the way in which they protect foreigners residing in their territory remains largely understudied.

Unlike this volume, past attempts at examining this nexus between emigration and immigration policies have usually focused on single case studies that highlight contradictions in the way sending states treat citizens abroad and foreign residents. In Europe for instance, Zincone (2006) noted that Italy's nationality law combined very generous features for emigrants' descendants with strict criteria for immigrants' descendants born in Italy. Similarly, other scholars also underlined in cases such as Mexico (Delano 2018) or Morocco (Cherti and Collyer 2015) that discourses on immigration and policies for foreigners residing in those states do not necessarily match with the protective stance towards citizens abroad.

In this volume, we aim to push the analysis of the immigration-emigration nexus further by examining the inclusiveness of non-EU states' welfare policies towards two categories of individuals in situation of international mobility: nationals residing abroad and foreigners residing in these countries. Before comparatively discussing our main findings for the 13 case studies, it is however important to distinguish them along demographic, political, and economic characteristics that are likely to create tensions - and possibly, contradictions- in the way these states treat emigrant and immigrant populations.

\subsubsection{Demographic Pressures}

The 13 countries included in our sample vary substantially in their historical migration trajectories, which could potentially constrain the way in which they define the access of minority populations to domestic welfare systems. As mentioned, all of them are relevant origin states for third-country nationals residing in the EU. Some 


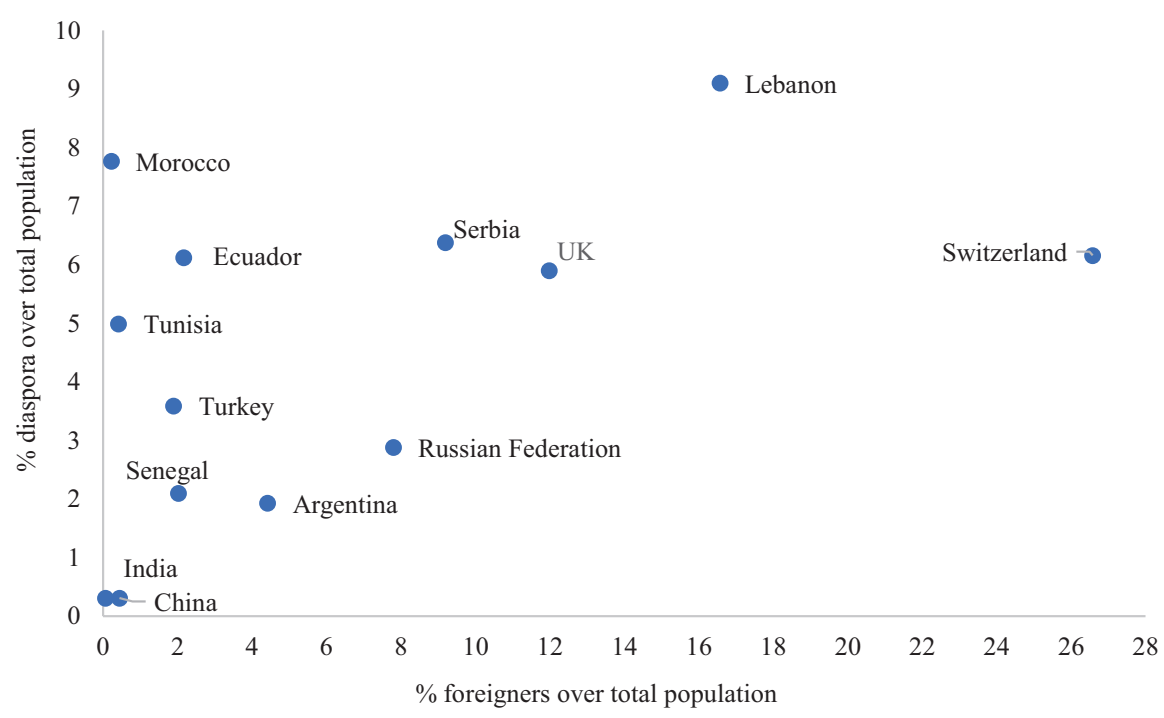

Fig. 1.3 Selected non-EU countries, by share of foreigners and diaspora over total population. (Source: Own elaboration. The data on stocks of foreign residents are from the UN dataset on International Migrant Stock, https://www.un.org/en/development/desa/population/migration/data/ estimates2/estimates17.asp (accessed 16 March 2020). The data on diaspora stocks are from the DIOC-E 2010/2011 dataset (https://www.oecd.org/els/mig/ dioc.htm, accessed 16 March 2020), covering emigrant population across 91 destinations (34 OECD countries and 57 non-OECD states). The percentages are calculated based on the total population data from the UN dataset on World Population Prospects, http://data.un.org/Data.aspx?q=population\&d=PopDiv\&f=variableI D\%3a12, accessed 16 March 2020. For both immigrants and emigrants, the reference year for the data is 2010)

also host sizeable immigrant communities due to continuous inflows for a prolonged period. Figure 1.3 illustrates this diversity by capturing the demographic weight of immigrants and emigrants in each selected country. Although all countries return rather large foreign and diaspora populations in absolute terms, the relative shares that these groups represent from the total population still vary widely, as some states have much larger populations in general.

Two clusters emerge for each group (immigrants and emigrants). In the case of the diaspora, the first cluster groups countries (Argentina, China, India, Russia, Senegal, Tunisia, and Turkey) in which nationals abroad constitute a rather limited segment of the total population (5\% or less). Hence, the non-resident populations of these countries have a more reduced demographic visibility, although in some cases- e.g. India-, the diaspora is very sizeable in absolute numbers. The countries included in the second cluster (Ecuador, Switzerland, Serbia, the UK, Morocco, and Lebanon) return much higher shares of nationals abroad, up to $9 \%$ of the total population in Lebanon. As for immigrants, in half of the countries analysed (China, Ecuador, India, Morocco, Senegal, Tunisia, Turkey), their share is still quite limitedless than $3 \%$. The fraction of foreigners is much higher in the second cluster 
comprising the rest of the countries analysed, reaching up to $12 \%$ in the UK, $16.6 \%$ in Lebanon, and $26.6 \%$ in Switzerland, respectively.

Immigrants and emigrants thus count with varying levels of demographic visibility across these countries and their demands for inclusion in the welfare system of these states may also vary significantly. When these minority groups are relatively small in demographic terms, ensuring their access to welfare may have little costs for these countries as, a priori, few individuals would potentially qualify as eligible claimants. At the opposite pole, when these groups are particularly sizeable, granting them access to welfare rights could be a costly decision, although more meaningful in terms of impact (for a similar argument, see Vintila and Lafleur 2020). In addition, states such as Lebanon, Switzerland, the UK or Serbia, which count with large numbers of immigrants and emigrants alike, may also have to ponder to which one of these groups they give preference to in terms of access to welfare.

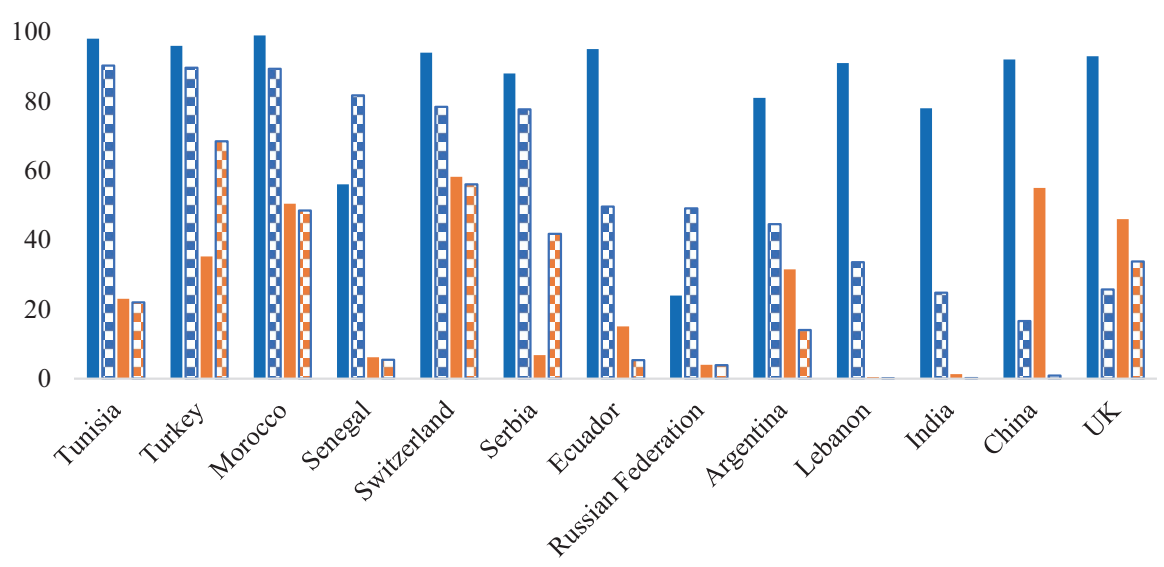

\footnotetext{
- \% nationals in high income countries over total diaspora population $\square \%$ nationals in the EU over total diaspora population - \% immigrants from high income countries over total immigrant population $\square \%$ EU immigrants from the total immigrant population
}

Fig. 1.4 Migrants coming from or going to high income countries and EU Member States from the total immigrant and emigrant population of the 13 non-EU countries. (Source: Own elaboration. The share of nationals residing in EU countries is calculated based on the DIOC-E 2010/2011 dataset (https://www.oecd.org/els/mig/dioc.htm, accessed 16 March 2020) covering emigrant populations across 91 destinations ( 34 OECD countries and 57 non-OECD states). The shares of nationals residing in high income countries and the shares of immigrants originating from the EU and from high income countries are calculated based on the UN dataset on Migrant stocks by origin and destination (https://www.un.org/en/development/desa/population/migration/data/estimates2/estimates17.asp, accessed 16 March 2020). For all groups, the reference year for the data is 2010) 


\subsubsection{Considerations Regarding the Composition of Migrant Stocks}

Apart from size, the composition of migration stocks may also constrain states' predisposition to ensure the access of mobile individuals to welfare. For instance, countries whose migrants come from or go to more economically developed states (especially high-income countries with more generous welfare regimes) may have fewer incentives to address the social protection needs of these minority groups. Figure 1.4 shows that more than a half of the emigrant populations of almost all states analysed here resides in high-income countries, up to more than $90 \%$ for Tunisia, Turkey, Morocco, Switzerland, Ecuador, Lebanon, the UK, and China. Consequently, policy makers in the homeland may be less reactive to these diaspora communities if they assume that their welfare needs may be better addressed by the (sometimes more developed) social protection regimes of their host countries, provided they have legal residence in the latter.

Furthermore, more than a half of the diaspora population of Tunisia, Turkey, Morocco, Senegal, Serbia, and Switzerland resides in EU countries, up to more than $90 \%$ for Tunisia. The share of non-resident nationals living in the EU is more moderate- but still significant- for Ecuador, Russia, and Argentina (more than four out of 10 emigrants from these countries reside in EU Member States); but substantially smaller for the UK, India or China. The case of Argentina, in particular, also allows us to underline another important element regarding the potential effect of the composition of migrant stocks on states' responsiveness to migrants' welfare. As shown by Gallo et al. (2006) with recent Argentine immigration to Southern Europe, a varying share of these migrants coming to the EU are dual nationals who already possess the nationality of an EU Member State prior to arriving in Europe or have facilitated access to such nationality upon arrival. As also discussed by Margheritis (this volume), such situation may trigger sending states to be less active in protecting their citizens abroad because of the assumption that the latter will be treated as nationals in the EU countries of settlement. More generally of course, the legal status (or undocumented status) of individuals in situation of international mobility - whether they are immigrants or emigrants - equally shapes the perception of state authorities about the necessity to intervene in favour of these populations.

Turning the scope to immigrants, only in Morocco, Switzerland, and China, 50\% or more of foreign residents originate from high-income countries, ${ }^{5}$ this share being substantially smaller (less than 10\%) for Senegal, Serbia, Russia, Lebanon, and India. In fact, in the latter two countries, only $1 \%$ of all immigrants come from high-income origin countries. The data also shows that, apart from Turkey and Switzerland in which half of all immigrants originate from EU Member States, in

\footnotetext{
${ }^{5}$ Besides the inflows of documented migrants, some of these countries have also received important irregular flows, as it is the case with migrants from sub-Saharan Africa in Morocco (see, for instance, the CARIM Migration Profile for Morocco, https://cadmus.eui.eu/bitstream/handle/1814/22441/MP_Morocco_EN.pdf? sequence=1\&isAllowed=y, accessed 16 March 2020).
} 


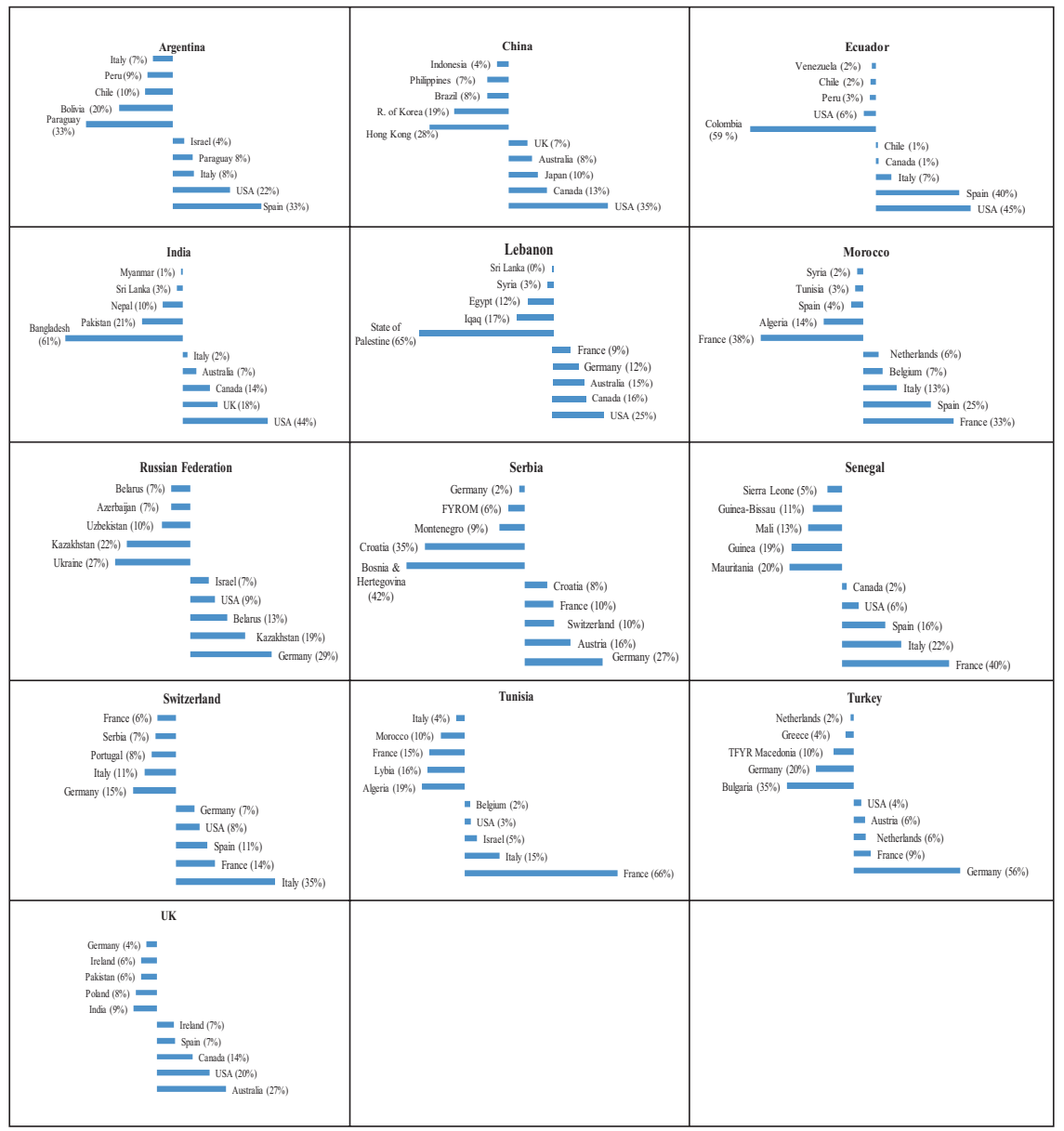

Fig. 1.5 Main origin countries of immigrants residing in the 13 non-EU countries (left side) and main destination countries of their nationals abroad (right side). Share over total immigrant and emigrant population of each non-EU country analysed. (Source: Own elaboration. The data on top destinations for the diaspora is from $\operatorname{OECD~(2015)~"Connecting~with~emigrants:~a~global~profile~of~}$ diasporas 2015" and it refers to emigrants (defined as foreign-born individuals by country of birth and their children born in destination countries) aged 15+ across 84 selected destinations (33 OECD countries and 51 non-OECD states)- reference year 2010/2011. The data on top origin countries of foreigners is from the UN dataset Trends in international migrant stock (reference year 2010), https://www.un.org/en/development/desa/population/migration/data/estimates2/estimates 17.asp, accessed 16 March 2020)

all others, the majority of foreigners have a non-EU background (up to $99 \%$ for Lebanon, India or China).

This variation in migration flows to and from Europe compared to other regions is also visible when looking at the specific origin countries of immigrants residing 
in these selected non-EU states, as well as the specific destination countries of their nationals abroad (Fig. 1.5). Unsurprisingly, among non-European destinations, the United States of America (USA), Australia or Canada stand out as the most important host countries for the emigrant populations of the 13 countries analysed here. Significant outflows are also oriented towards EU destinations, mainly Italy, Spain, France, Germany, Belgium or the Netherlands. For Morocco and Serbia in particular, the main five destination countries of their diaspora are European countries. Figure 1.5 also confirms the tendency already highlighted for European diaspora populations (Lafleur and Vintila 2020c) of a high concentration of emigrants in particular destination countries only. For instance, the first two host countries of Argentinean, Ecuadorian, Indian, Moroccan, Senegalese, Tunisian or Turkish nationals already sum up more than a half of the total diaspora of these countries, with more than $50 \%$ of all non-resident Tunisian or Turkish citizens being concentrated in one country in particular. In some cases, a common language and/or past colonial ties (the case of Indians in the UK, Argentines and Ecuadorians in Spain, UK citizens in Australia and the USA, or Moroccans in France) facilitate this selection of specific destination countries. Regardless of the reasons for diaspora's geographical concentration in particular destinations, having a high share of nationals abroad residing in a specific state may also incentivize origin countries to become more attentive to the needs of that particular group.

The situation is more diverse when looking at the main origin countries of immigrants residing in these 13 countries. In China, Ecuador, India, Lebanon, Russia, and Senegal, the main immigrant groups originate from non-EU countries; and in Ecuador, India, and Lebanon, more than a half of all foreigners come from a single country. In Argentina, Morocco, Serbia, and Turkey, the first two migrant communities account for more than $50 \%$ of all immigrants, the demographic concentration of foreigners being more evenly distributed across different groups in the other countries analysed. Often, the most sizeable immigrant communities originate from neighbouring states (see the cases of India, Senegal, Serbia or Russia). In other cases, the presence of specific communities is due to strong migratory ties with origin countries (Italians in Argentina, Germans in Turkey, Indians and Pakistanis in the UK, or French nationals in Morocco).

\subsubsection{Economic and Political Tensions}

The size and composition of migrant stocks may influence states' behaviour regarding the social protection of minority groups, but so is the economic or political leverage that these communities might have on national governments. The example of diaspora populations helps us illustrate this point. As mentioned, based on the size of the diaspora, we can identify two clusters of countries. First, there are those counting with a relatively small diaspora in which nationals abroad account for 5\% or less of the population (Argentina, China, India, Russia, Senegal, Tunisia, and 


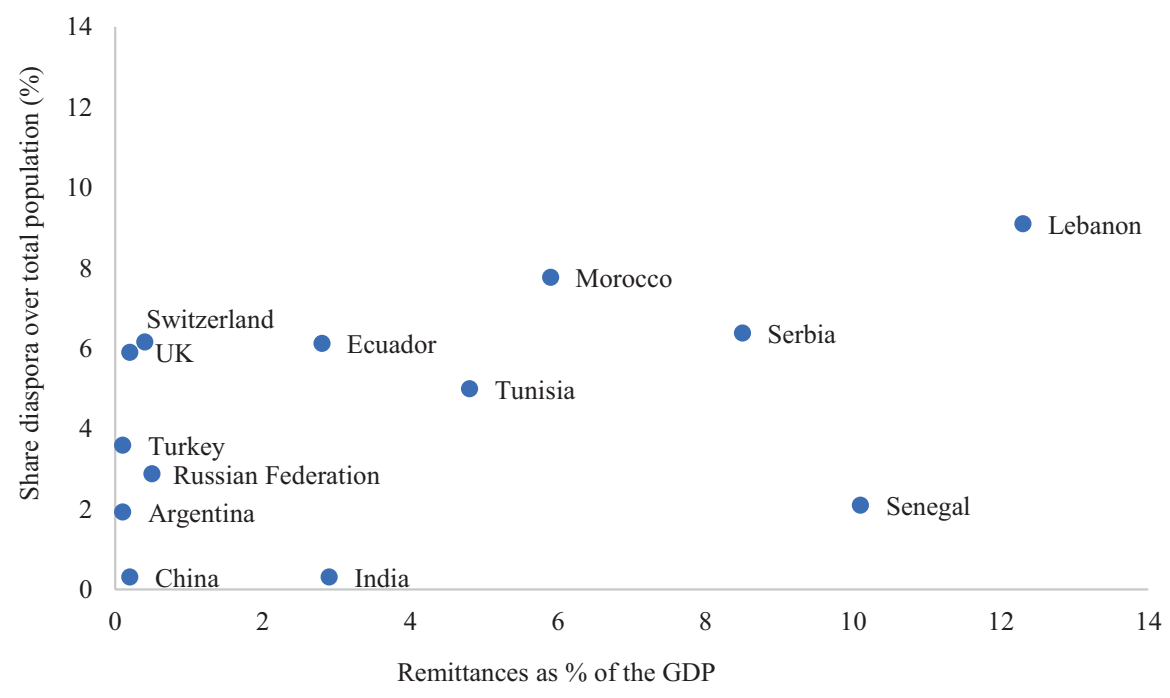

Fig. 1.6 Non-EU countries by share of diaspora (vertical axis) and remittances as share of the GDP (horizontal axis). (Source: Own elaboration. The data on remittances are from the World Bank dataset on Migrant Remittances Inflows (reference year 2018, https://data.worldbank.org/ indicator/BX.TRF.PWKR.DT.GD.ZS?locations $=$ SN, accessed 16 Match 2020). See detailed sources for diaspora data in Fig. 1.3)

Turkey). The second cluster includes countries with more sizeable diaspora groups (Ecuador, Switzerland, Serbia, the UK, Morocco, Lebanon).

The first group of countries may not be particularly pro-active when it comes to diaspora's inclusion into domestic welfare systems not only because of its relatively small size, but also given that nationals abroad make a rather limited financial contribution to the homeland via remittances. As illustrated in Fig. 1.6, their remittances usually represent $0.5 \%$ or less of the GDP (higher in India and Tunisia). The clear exception from this first group is Senegal: although the Senegalese diaspora is relatively small, its impact for the homeland economy is particularly high since remittances sent from abroad account for more than 9\% of the GDP. This, in turn, may raise awareness amongst policy makers in Senegal about the importance of the diaspora, thus making them more likely to become attentive to the needs of this population. At the opposite pole, policy makers in countries included in the second cluster are already faced with a strong demographic visibility of diaspora groups; and their responsiveness may be further incentivised by the economic leverage of non-residents. This is particularly the case for Morocco, Serbia, and Lebanon, countries in which an important share of the GDP is due to diaspora's remittances. This external financial help plays a relevant role in boosting income in the homeland, including that of the most vulnerable groups of the population (Harrigan and El-Said 2014; Tabar and Denison this volume). 
Diaspora's economic contribution may thus shape how sending states behave towards this group; and this is even more likely to happen when nationals abroad also count with voting rights in homeland elections. All countries analysed here, except for China and India, ${ }^{6}$ grant voting rights to their non-resident citizens for national legislative and/or presidential elections (with important restrictions in the UK). As shown in past studies, emigrant turnout in homeland elections is influenced by different factors (party mobilization, voter registration requirements, etc.), but usually tends to be lower than that of domestic voters (Lafleur and SánchezDomínguez 2015; Ahmadov and Sasse 2016; Østergaard-Nielsen and Ciornei 2019). Yet, as demonstrated in the Turkish case, parties in sending states may try to appeal to voters abroad by developing policies to address specifically their needs (Mencutek and Baser 2018).

Similar economic and political constrains could also shape states' inclusiveness towards immigrants. For instance, Switzerland stands out in our sample as the state with the highest share of immigrants, reaching up to $27 \%$ of the population. Overall, foreign-born individuals constitute $32 \%$ of all employees in Switzerland, with a high share $(47 \%)$ working as managers, professionals, or technicians and associate professionals. ${ }^{7}$ Their strong economic leverage is further complemented by the fact that, in some Swiss cantons, foreigners also have the right to vote in local and regional legislative elections and referendum, as well as in local mayoral and regional presidential elections. ${ }^{8}$ At the opposite pole, in Turkey, for instance, foreigners account for a rather small share of the population. They also face rather unfavourable conditions in terms of labour market mobility, while being excluded from political participation as they cannot joint political parties, cannot vote nor have their own associations or media unless one of the directors is a Turkish citizen. ${ }^{9}$ Consequently, this configuration of factors may reduce the likelihood of Turkish authorities to become particularly responsive to their needs, including their social protection needs.

Drawing on these initial expectations, the next section maps out some of the main findings of the country chapters included in this volume regarding the way in which non-EU states respond to the inclusion of immigrant and emigrant populations in their domestic welfare regimes.

\footnotetext{
${ }^{6}$ Despite ongoing discussions regarding the implementation of proxy voting, India allows nonresident nationals to vote only if they travel back to India during the election day (see the diaspora chapter in this volume).

${ }^{7}$ Eurostat data on Employees by migration status, educational attainment level, occupation and working time, http://appsso.eurostat.ec.europa.eu/nui/setupDownloads.do. Accessed 16 March 2020.

${ }^{8} \mathrm{http}: / /$ globalcit.eu/conditions-for-electoral-rights/. Accessed 16 March 2020.

${ }^{9}$ See MIPEX results for Turkey, http://www.mipex.eu/turkey. Accessed 16 March 2020
} 


\subsection{What Kind of Social Protection for Mobile Individuals Moving from/to Non-EU Countries?}

\subsubsection{Access to Social Protection for Foreigners: Between Equal Treatment and (In)Direct Disentitlement}

The analysis of the 13 countries included in this book points towards interesting patterns of convergence in how they define the link between migration and welfare in social policy legislations. Figure 1.7 comparatively maps the type of access that non-national residents and non-resident nationals have to specific social benefits, when compared to national residents.

The figure confirms the pattern previously discussed according to which both immigrants and emigrants are sometimes excluded from certain welfare schemes (which are quite generalised across the EU) simply because the countries analysed here have not implemented yet such programs, not even for their resident nationals. Examples of such general grounds of exclusion that affect migrants and non-migrants alike can be identified in the area of unemployment benefits (especially unemployment assistance), non-contributory old-age pensions, social assistance, and family-related benefits (especially parental benefits, but also- less frequently- paternity and child benefits). The absence of such social protection schemes is particularly visible in Lebanon, which has not implemented yet specific programs for unemployment benefits, sickness cash benefits, social assistance or several family-related benefits. To a lesser extent, this is also the case for China (still failing to provide sickness benefits in cash or paternity, parental, and child benefits) and Senegal (which has not integrated yet unemployment schemes or general social assistance programs for the most vulnerable).

Apart from these general limitations applicable to all groups, when it comes to immigrants in particular, our findings show that the contributory logic generally prevails over nationality in access to welfare. In most countries and for almost all benefits - regardless of their contributory/non-contributory nature -, nationality becomes an irrelevant factor once the wage-earning criterion is fulfilled. This confirms the trend of employment-driven inclusion of foreign workers in domestic welfare systems already identified for other countries (see Vintila and Lafleur 2020 for EU Member States).

Yet, country chapters in this volume also discuss how different migration and labour-market conditions may still hinder foreign workers' access to welfare even when national legislations do recognize them as eligible claimants. To begin with, the strong labour market informality across many countries analysed here stands out as an important obstacle for immigrants' access to welfare. Secondly, foreigners may find it more difficult than nationals to comply with the period of prior employment that often conditions access to cash benefits, especially if we consider how language barriers or labour market discrimination practices could hinder their 

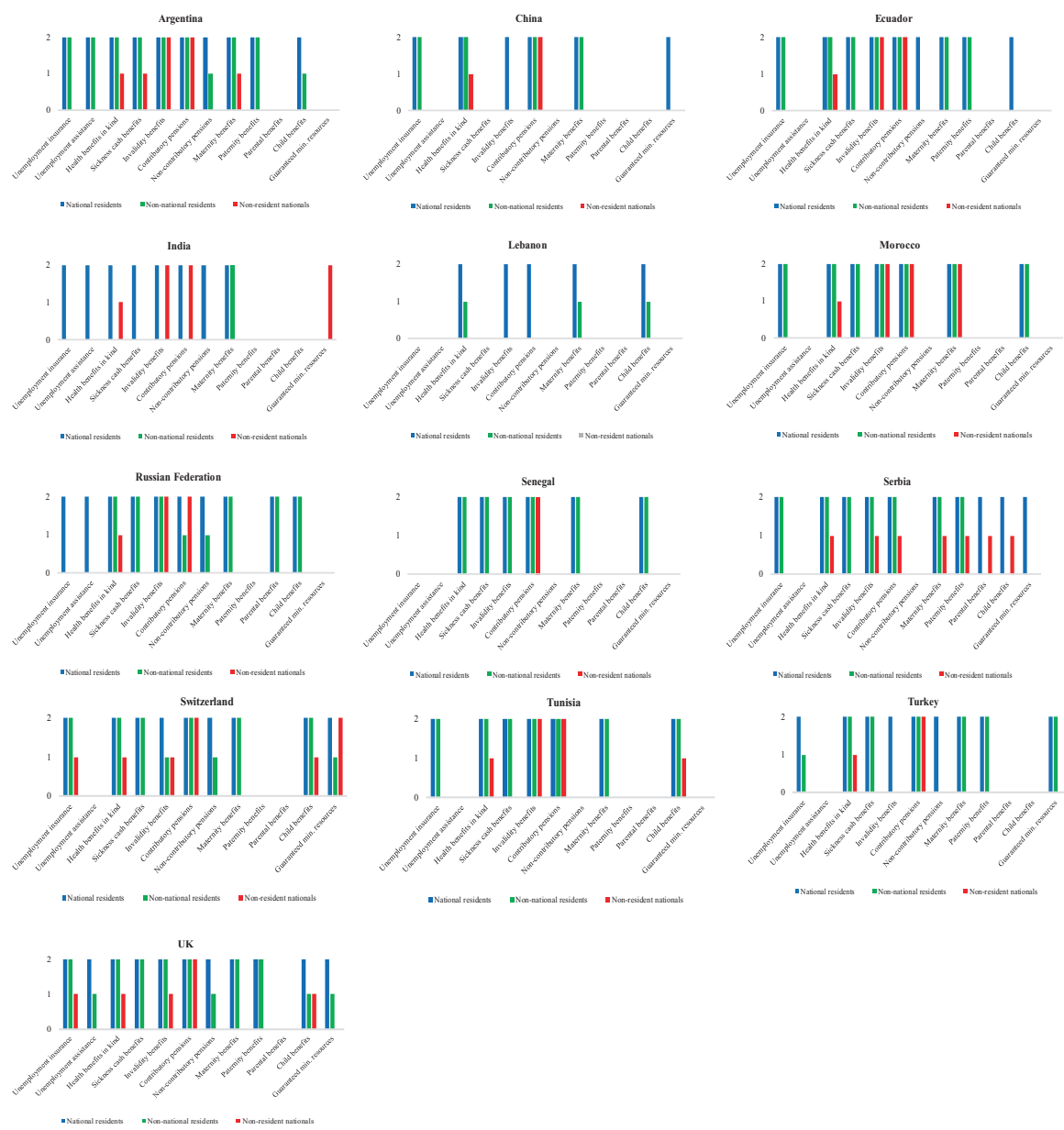

Fig. 1.7 Access of national residents, non-national residents and non-resident nationals to social benefits. (Source: Own elaboration based on the MiTSoPro dataset (policies in place at the beginning of 2019). A value of " 2 " indicates that the benefit exists in the country and the groups analysed here are entitled to access it upon fulfilment of the general eligibility conditions. A value of " 1 " indicates that the benefit exists, but only certain categories of individuals (such as only those originating from specific countries in the case of foreigners or only those affiliated to special schemes reserved for citizens abroad in the case of diaspora) can access it, instead of being open to all individuals from each group (i.e. all immigrants and emigrants, in general). A value of " 0 " indicates that individuals do not have access to a specific benefit. When all three groups analysed return the value " 0 " for a specific benefit, it means that the benefit does not exist in that specific country. In the case of the guaranteed minimum resources scheme, there are cantonal differences in Switzerland)

possibility to find stable jobs. Thirdly, since several benefits granted by these nonEU countries cover formal workers only, migrants may find it hard to obtain this status in the first place especially since, unlike non-migrants, foreigners must first regularise their immigration status and obtain the right to work. As explained in 
several chapters, the acquisition of the right to work sometimes requires a rather complicated administrative procedure (see chapters on Argentina and Tunisia; or the case of Ecuador where foreigners' right to work in the private sector is conditioned by the obtainment of a certificate from the Labour Ministry stating that their employment does not affect the national policy on employment and human resources).

Country chapters also illustrate instances of direct exclusion of foreigners from specific types of welfare rights. In some countries, non-national residents are not entitled to claim certain benefits, whereas in others, they must comply with additional eligibility conditions which do not apply for national residents. For instance, Bertolini and Clegg (this volume) discuss in this volume how nonEEA citizens who are subject to immigration control in the UK are excluded by the terms of their visas from claiming social benefits that fall under the legal definition of 'public funds', including demogrants, means-tested benefits and tax credits. Similarly, foreigners are not entitled to claim social assistance in Serbia or China, as cash benefits for individuals in need are offered only to citizens of these countries. In the area of family benefits, the birth grants granted by Turkey are exclusively reserved for national citizens, the same applying for the late maternity leave in China or the cash parental allowance in Serbia. Unlike their national counterparts, foreigners can access the Universal Child Allowance in Argentina only after three years of residence. In other countries, access to family benefits is allowed only for specific groups of foreigners as it happens in Lebanon, where only foreigners originating from countries that maintain a reciprocal treatment for Lebanese nationals can receive maternity and child benefits.

A similar tendency of restrictiveness towards foreigners' access to social assistance or certain family benefits was also found across EU countries (Vintila and Lafleur 2020). Yet, some non-EU states show that this restrictiveness can be further extended to other policy areas in which foreigners generally benefit from equal treatment in the EU. One example is in the area of unemployment. Although foreigners can generally claim unemployment benefits under the same eligibility requirements as nationals in most countries analysed here, in Russia, they are still excluded as potential beneficiaries of cash benefits in case of job loss, thus being entitled only to job search services. Similarly, foreigners residing in India cannot claim the recently introduced Unemployment Assistance Scheme, as this program is exclusively reserved for Indian citizens; whereas in Turkey, unlike their national counterparts, non-nationals must have resided for at least a year to qualify for unemployment benefits.

Certain instances of direct exclusion of non-national residents are also detected in the area of old-age pensions. As explained for the Indian case in this volume, foreigners cannot access the national pension scheme, whereas the chapter on Lebanon discusses how foreigners (except Palestinians with a valid work permit) are excluded from accessing the Lebanese end-of-service indemnity. Russia also excludes temporary foreign residents as potential beneficiaries of a contributory pension, and only those holding the permanent residence status (which can be claimed within three years after having obtained the temporary residence permit) 
qualify for this pension. In some cases, access to non-contributory pensions is also restricted. By way of example, foreigners cannot access this pension in India, whereas the Turkish social assistance scheme for the elderly is reserved only for resident Turkish nationals. Carmona Barrenechea et al. (this volume) also show how non-contributory pensions in Argentina are granted to Argentine citizens or naturalised migrants with at least 10 years of prior residence, or to foreigners with a minimum of 20 years of residence who continue to live in Argentina once the pension is granted. In other countries, only specific groups of foreigners are entitled to claim non-contributory pensions. For instance, Switzerland restricts the access to this pension only to nationals of EU or European Free Trade Association (EFTA) countries who are permanent residents; whereas in Russia, only foreigners who are permanent residents and have lived in the country for at least 15 years can claim this pension.

Such examples demonstrate that many of these non-EU countries have opted for a more protectionist and restrictive stance when defining who is legally entitled to claim welfare, this implicitly leading to more frequent instances of exclusion of foreigners when compared to EU countries. Overall, India and Lebanon seem to put forward a more exclusionary approach towards immigrants, as the latter are entitled to claim very few of the welfare provisions implemented in these countries. The Indian case is particularly noteworthy as apart from maternity benefits, foreigners do not qualify as eligible applicants for any of the other social protection schemes offered by the Indian government. At the opposite pole, in Morocco, Senegal or Tunisia, foreigners always have legal access to the welfare entitlements analysed here although, as discussed, some of these countries- especially Senegal- a priori have fewer social protection schemes when compared to other countries. Yet, even when foreigners do have access to welfare under equal conditions as national residents, in some cases, the take-up of such benefits may have negative consequences. As explained in this volume, the Russian Federal Migration Service may recall a previously issued residence permit for foreigners who cannot provide for themselves or their families at a level that is higher than the regional poverty line. Similarly, foreigners living in Switzerland may lose their residence permits if receiving social aid. As shown in this book, as a result of a popular vote in 2014, new provisions now stipulate that Swiss residence permits are not issued to foreigners who apply for non-contributory benefits paid for old-age, survivors or disability via the federal complementary scheme, while foreign jobseekers (except for EU/EFTA) are excluded from claiming social assistance.

Despite of that, some country chapters also provide interesting examples of how certain states sometimes privilege specific migrant groups in their national legislations regulating access to welfare. This preferential treatment of certain nationalities operates either indirectly- by facilitating their access to residence permits and, implicitly, to work and welfare rights-, or directly - by granting them easier access to social benefits compared to other foreign nationalities. In some cases, this facilitated access derives from cooperation initiatives at the supranational level; in others, 
it is the result of special (historical, political or strategical) ties with origin countries. By way of example, Argentina is part of the MERCOSUR Multilateral Agreement on Social Security ${ }^{10}$ with Brazil, Uruguay, and Paraguay. This agreement covers access to health care, old-age and disability benefits and grants migrant domestic workers pension portability rights. MERCOSUR nationals residing in Argentina are also granted longer temporary residence permits compared to other nationalities, while also benefiting from lower visa fees. Similarly, Switzerland is part of the Agreement on Free Movement of Persons and the EFTA Convention aiming to coordinate various national social security systems, offering equal treatment of nationals of the other signatory partners with Swiss citizens and covering a wide array of social insurance benefits. Until recently an EU Member State, the UK has granted access to most welfare rights to foreigners originating from EEA countries under the EU law; although many changes in this group's access to social rights are likely to be introduced in the future. Preferential treatment of certain nationalities is also observed in Lebanon, where Palestinians are exempted from paying the work visa fees and, unlike other foreigners, they can also receive the end-of-service indemnity. This case is particularly interesting, especially since Lebanon stands out as the non-EU country from our sample that mostly restricts the pool of foreign residents who can access social protection. As explained in this volume, only foreigners originating from countries which provide equal treatment to Lebanese citizens based on a reciprocity clause are eligible to enroll in the National Social Security Fund that is the main provider of health care, end-of-service indemnity, and family benefits. However, this currently applies only for citizens of France, the UK, Belgium, and India. Finally, Russia also favours specific nationalities by granting them equal access to social security benefits (except for pensions). This applies to nationals of Belarus (based on a bilateral agreement) and nationals of countries of the Eurasian Economic Union (including Belarus, Kazakhstan, Armenia, and Kyrgyzstan).

\subsubsection{The Case of Non-Resident Nationals: Formal Exclusion from the Home Country's Welfare Regime, with Some Exceptions}

As mentioned, individuals' employment status is a key element ensuring their access to social protection across the 13 countries analysed in this book. Often, this also implies residence in these countries, a requirement that directly excludes nationals living abroad as potential beneficiaries of welfare provisions from their countries of nationality. As discussed in the country chapters, when deciding to move abroad permanently, citizens of most of the countries examined here

\footnotetext{
${ }^{10}$ See: https://www.mercosur.int/. Accessed 16 March 2020.
} 
generally lose their entitlement for social benefits from the homeland. Residence in the country is usually mandatory to receive unemployment benefits, non-contributory pensions, and (most) family benefits, reason for which non-residents cannot access them from abroad. The same form of exclusion also operates in the area of social assistance: when specific social assistance programs exist (Fig. 1.7), they tend to be strictly linked to the residence principle (for instance, in Serbia) or even to local residence in particular areas of the country that grants them (see the example of China). Overall, sending states' restrictiveness towards diaspora's access to welfare seems particularly visible in Lebanon, Senegal and, to a lower extent, also in Turkey and China where non-residents can claim very few welfare benefits.

Yet, there are three important exceptions from this general trend of restrictiveness towards diaspora populations. First, there are certain policy areas for which exportability is more frequently stipulated in national legislations. Figure 1.7 shows that all selected countries - except for Lebanon ${ }^{11}$ - allow their nationals living abroad to continue receiving a contributory pension despite their physical absence. However, in some cases, there are certain limitations. For instance, exportability of contributory pensions from Serbia is allowed only when included in bilateral agreements with destination countries. In Ecuador- which allows its nationals abroad to voluntarily contribute to the Ecuadorean pension scheme-, contributory pensions are not technically exportable, but they can still be accessed from abroad as long as the beneficiary keeps a bank account in Ecuador where the pension will be paid. Similar regulations apply for invalidity benefits, which represent the second most important exception to the strong link between welfare and residence in a country. States such as Argentina, Morocco, Russia (only for the contributory disability pension), the UK (with restrictions) or Serbia (only when covered by bilateral agreements) allow for the exportability of invalidity benefits. In any case, this flexibility of states in allowing the exportability of old-age pensions or invalidity benefits is not peculiar to these countries, being frequently observed also among EU Member States (Vintila and Lafleur 2020).

A second relevant exception rests in a series of policy innovations that several non-EU states have developed in the attempt to respond to the social protection needs of their diaspora. Such policies often consist in facilitating non-residents' access to the homeland social protection regime. Figure 1.7 highlights a clear example in this regard in the area of health care. Most non-EU countries analysed here authorize their non-resident citizens to maintain some type of health coverage in the homeland, mainly by allowing them to continue paying contributions from abroad that open access to the healthcare system back in origin countries. Such policy innovations can also refer to the design of ad-hoc schemes for citizens abroad, that are different from the general welfare programs accessible to residents. In the field of health care, India recently introduced a specific insurance scheme - the Pravasi Bharatiya Bima Yojana- aiming to ensure the protection of

\footnotetext{
${ }^{11}$ As explained in the country chapters, the Lebanese public pension schemes only covers a very limited segment of non-resident nationals, namely civil servants and those working in the military.
} 
Indian workers abroad in destination countries where they have limited welfare rights (e.g. Gulf countries). This scheme covers insured workers for accidental death, permanent disability leading to loss of employment while abroad, repatriation, and reimbursement of hospitalisation costs. India also created the Indian Community Welfare Fund (ICWF), a means-tested social assistance initiative aiming to respond to exceptional hardship faced by nationals abroad. Other countries also put forward similar schemes specifically designed to address diasporas' social risks. For instance, Tunisia created a program that allows its citizens who work in destination countries with which Tunisia has not signed a social security agreement to voluntarily join the Tunisian insurance system. This provides health coverage to both the Tunisian worker living abroad (during temporary stays in Tunisia, for instance) and to family members remaining in Tunisia. On a much more limited scale, Morocco also set up a specific program called "Marhaba" that grants access to health care to citizens residing abroad who return temporarily to Morocco during the summer. In the field of pensions, Serbian authorities have responded to the needs of Serbian citizens who work abroad and are not compulsory insured in destination countries by allowing them to voluntarily join the Serbian pension insurance scheme. As for social assistance, Switzerland created a separate scheme for non-resident nationals who are in a situation of need and cannot support themselves.

Thirdly, beyond general exportability and/or specific social protection schemes for the diaspora, country chapters in this volume also show how sending states' responsiveness to nationals abroad is often reflected in the bilateral or multilateral

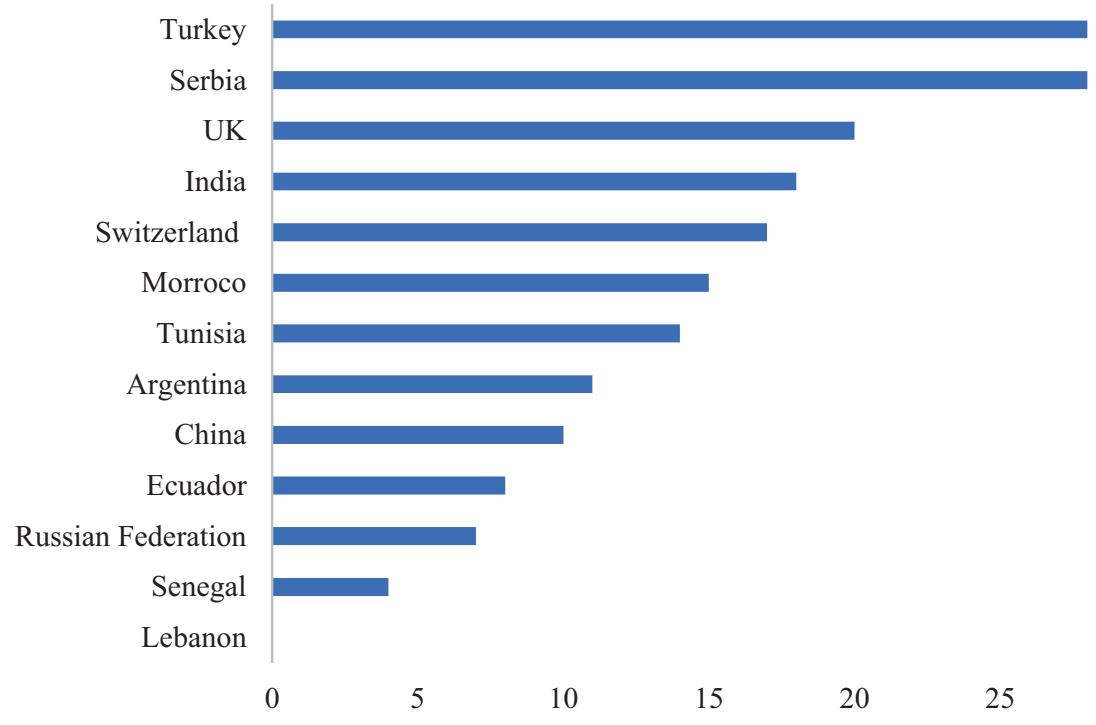

Fig. 1.8 Number of bilateral social security agreements signed by non-EU countries. (Source: Own elaboration based on the MiTSoPro dataset) 
social security agreements they engage in. Such agreements usually grant certain migrant groups with an extra layer of protection when compared to what domestic social security legislations provide to all migrants in general (Sabates-Wheeler and Koettl 2010). Regarding multilateral forms of cooperation, the examples of MERCOSUR (for Argentina) and the EFTA Convention and the Agreement on Free Movement of Persons (for Switzerland) clearly illustrate how multilateral social security arrangements can improve the access to social protection of nationals of signing partners. As for bilateral arrangements, Fig. 1.8 shows that Turkey, Serbia, the UK, India, and Switzerland have been particularly pro-active in engaging in bilateral social security cooperation, whereas Senegal and Lebanon signed very few conventions in this area. However, the country chapters also show that there is still substantial variation in the types of benefits that these agreements actually cover; as well as in the way these states managed to secure social security agreements with the main destination countries of their diaspora.

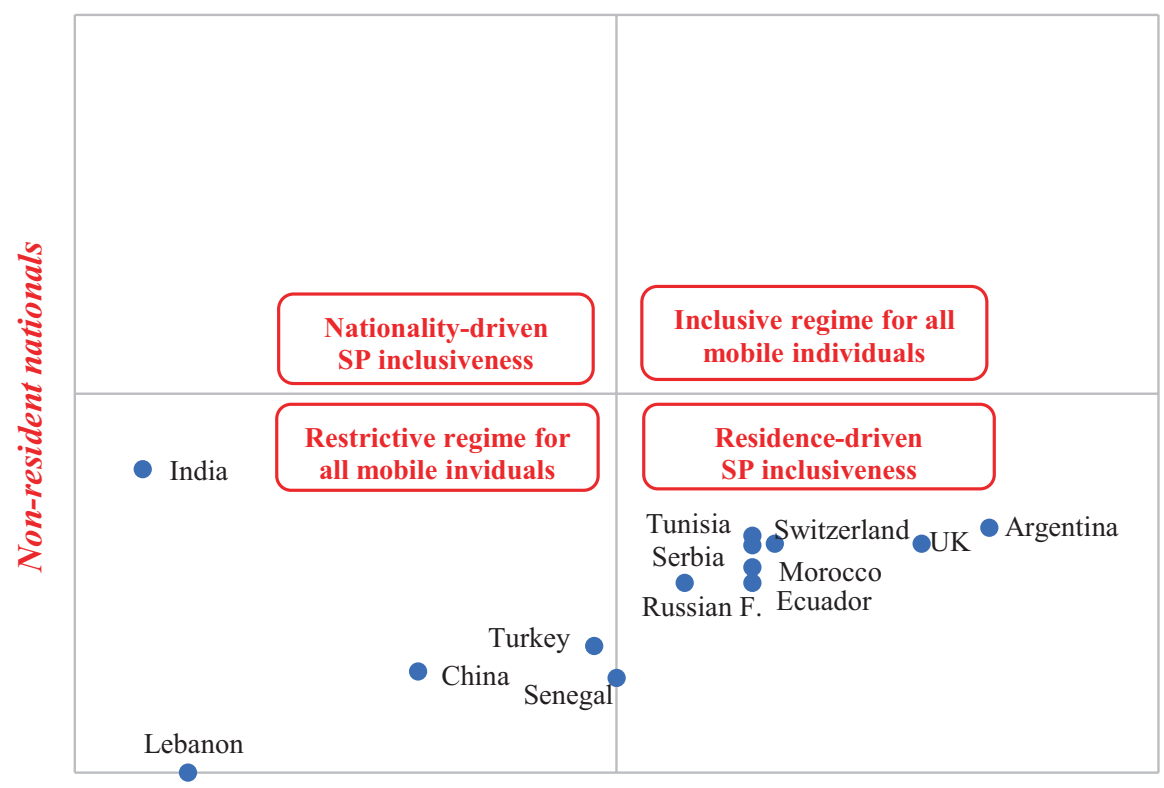

Non-national residents

Fig. 1.9 Non-EU sending states' welfare inclusiveness for immigrant and emigrant populations. (Source: Own elaboration based on MiTSoPro data. The horizontal axis captures states' inclusiveness towards immigrants, whereas the vertical axis refers to emigrants. Both axes are calculated based on the average values of inclusiveness/restrictiveness of access that they return for each policy area (see details in Fig. 1.7)) 


\subsubsection{Protecting Immigrants and Emigrants: A Trade-Off for Welfare States?}

Figure 1.9 summarises our comparative findings regarding the inclusiveness of the selected non-EU states regarding the access of migrant populations to their domestic welfare systems. In terms of general social protection provision, our findings indicate that none of these countries have put forward very inclusive social protection regimes for both immigrants and emigrants at the same time. Almost all of them- except for India- actually seem more inclined to grant access to social benefits for their non-national residents when compared to non-resident nationals. The principle of territoriality remains a key element conditioning welfare entitlement in these countries; and it generally seems to be a more relevant factor for accessing social protection than nationality. Moreover, the fact that most of these countries usually allow their diaspora to access very limited welfare provisions from the homeland could also be linked to the fact that, as explained above, a significant share of their nationals abroad reside in high-income destination countries which often have strong welfare regimes.

Figure 1.9 also allows us to identity two clusters of countries. A first cluster includes states that put forward a rather restrictive approach to both immigrants and emigrants alike, as they offer few welfare benefits to mobile individuals. This group includes Lebanon, India, Turkey, China, and Senegal. With the exception of Lebanon (which returns a very sizeable foreign community, with immigrants representing $16.6 \%$ of the population), the rest of the countries in this first cluster host relatively few foreigners, with non-national residents accounting for less than $2 \%$ of the population. In Lebanon and Senegal, this rather restrictive attitude vis-à-vis immigrants' access to welfare - and their implicitly protectionist approach regarding the social protection of resident citizens- is perhaps unsurprising considering that these countries a priori have rather fragile social protection systems and limited resources to be allocated to the area of welfare. As mentioned, both countries return quite low levels of social protection expenditure. Senegal also stands out by its high share of informal employment, worrying poverty levels, and limited gross national income per capita; although it still adopts a more inclusive stance towards immigrants' access to benefits when compared to Lebanon. Although India also falls in this first cluster- and it shares certain socio-economic features with Senegal or Lebanon, such as the high labour market informality and poverty levels-, this country still scores slightly higher than other non-EU states in terms of welfare provisions offered to its population residing abroad.

The remaining non-EU states included in this volume form a second cluster. They share a common denominator in the fact that seem more inclusive towards immigrants than emigrants when it comes to granting them access to the domestic welfare system. Many of these states allow foreigners (especially foreign workers) to claim social benefits, but they remain reluctant to extend such benefits to their nationals residing abroad. Within this second group, Argentina, the UK, and Switzerland seem the most inclusive countries towards immigrants' access to social 
protection. As discussed by Margheritis (this volume), Argentina has been historically considered as an immigration country, this approach being closely linked to Argentina's state and nation-building processes. On the other hand, both the UK and Switzerland stand out in our sample as countries returning high shares of foreigners in the total population. As previously mentioned, Serbia and Russia also report quite sizeable non-national groups; and, in general, they are relatively inclusive when it comes to allowing foreigners to access their social protection system.

Going back to diaspora populations, our findings indicate that most non-EU sending states return rather moderate or even limited responsiveness to nonresidents' social protection. The majority of them have not even developed specific policies by which their consular authorities (or other homeland institutions) are required to assist citizens abroad when applying for home or host country welfare benefits. Among these, China and Morocco, however, have an explicit policy of financially supporting not-for-profit organizations which assist nationals abroad in the area of social protection. On the other hand, Switzerland and Tunisia do have formal policies that clearly identify — but only in very general terms - a formal responsibility for homeland authorities to support citizens abroad in their application process for accessing welfare. Such homeland assistance is even stronger for Ecuador and Turkey, as both states identify specific missions of social protection assistance. As discussed in this volume, Ecuador created the position of representative of the Office of the Human Rights Ombudsman that advises and supports citizens abroad to access rights in the home and host countries; whereas Turkey has created the position of attaché of the Ministry of Family and Social Policies in consulates, with the aim of assisting citizens abroad to access welfare.

In addition to what they provide to nationals abroad or how they facilitate nonresidents' access to welfare, some of these countries have also put forward a quite extensive institutional framework to engage with diaspora populations. While this framework may not appear, at first sight, as directly related to welfare concerns, the existence of such institutions provides us an indication of the visibility of diaspora issues in homeland politics. In our introduction to the second volume of this book series (Lafleur and Vintila 2020c), we used the concept of descriptive infrastructure to describe the set of "home country institutions that explicitly acknowledge the diaspora as main reason for their existence, while formally being granted the mission to act in its interests (including specific social protection interests)". More precisely, we identified three types of institutions: consulates (excluding honorary consulates), governmental institutions (at the ministry and sub-ministry levels, specifically acknowledging the diaspora in their name, while also acting in emigrationrelated issues) and interest-representation institutions (members of Parliament elected by citizens abroad and official consultative bodies and mechanisms allowing the diaspora to voice its concerns).

Looking at the existence of such institutions across the 13 non-EU countries analysed here, we observe a quite mixed picture. Table 1.4 shows us that not all these countries count with an equal representation abroad. The two countries with a long history of post-war emigration to the EU- Morocco and Turkey - return the strongest consular presence in their top five destination countries. However, as 
Table 1.4 Diaspora institutional framework of non-EU selected states

\begin{tabular}{l|l|l|l|l|l}
\hline Country & $\begin{array}{l}\text { N consulates in } \\
\text { top five } \\
\text { destinations }\end{array}$ & $\begin{array}{l}\text { Ministry- } \\
\text { level } \\
\text { institution }\end{array}$ & $\begin{array}{l}\text { Sub- } \\
\text { ministerial } \\
\text { institutions }\end{array}$ & $\begin{array}{l}\text { Reserved seats } \\
\text { national } \\
\text { Parliament }\end{array}$ & $\begin{array}{l}\text { Diaspora } \\
\text { representation } \\
\text { (consultative) }\end{array}$ \\
\hline Argentina & 19 & No & Yes & No & No \\
\hline China & 28 & No & Yes & No & Yes \\
\hline Ecuador & 23 & Yes & Yes & Yes & Yes \\
\hline India & 12 & No & Yes & No & Yes \\
\hline Lebanon & 12 & Yes & Yes & No & Yes \\
\hline Morocco & 41 & No & Yes & No & Yes \\
\hline Russian F. & 17 & No & Yes & No & Yes \\
\hline Senegal & 14 & Yes & Yes & Yes & Yes \\
\hline Serbia & 15 & No & Yes & No & Yes \\
\hline Switzerland & 17 & No & Yes & No & Yes \\
\hline Tunisia & 15 & No & Yes & Yes & No \\
\hline Turkey & 33 & No & Yes & No & Yes \\
\hline UK & 28 & No & No & No & No \\
\hline
\end{tabular}

Source: Own elaboration based on MiTSoPro data

discussed in this volume, the quality of the assistance offered by Moroccan consulates abroad has often been questioned by its beneficiaries, this triggering Morocco's attention and efforts in trying to improve its consular services. As previously shown in Fig. 1.5, the Moroccan diaspora is more evenly distributed across different EU countries (for instance, 33\% of all Moroccans living abroad reside in France, 25\% in Spain and $13 \%$ in Italy), whereas more than a half of the Turkish diaspora concentrates in a single destination country (Germany). Morocco also seems to be more responsive in terms of allowing its nationals abroad to access homeland benefits (Fig. 1.9), although Turkey has implemented a more developed consular assistance in the area of social protection for its non-resident citizens. At the opposite pole, India and Lebanon return the lowest number of consulates in top destination countries, although the weight of their diaspora over the total population varies from $0.3 \%$ in India to $9.1 \%$ in Lebanon, respectively. On the other hand, countries such as China, Argentina, Senegal or Russia, in which non-resident nationals count with a limited demographic share (less than $3 \%$ of the population), return more than 15 consulates in their top five destination countries. In some cases, this number is not necessarily reflecting those states' interest in the needs of their citizens abroad, but rather their desire to increase their economic and political influence. As discussed in this volume, this seems to be the case for China: its diaspora population has historically played a fundamental role in the modernisation and development projects implemented in China, with a strong state emphasis on encouraging investment and return of highly skilled Chinese from overseas.

Table 1.4 also shows that very few of these countries have created ministry-level institutions for their nationals abroad. Currently, such institutions exist only in Lebanon, Senegal, and Ecuador, countries that actually provide limited access to 
homeland welfare benefits for their diaspora. As they ensure visibility at the highest governmental level and usually come with budgets for diaspora-related issues, these ministries are providing very clear indications of homeland's interests in this matter. However, because of their political nature, such institutions are also the ones that are most likely to come and go as governments (or their priorities) change. This volatility is illustrated with the examples of India, Morocco, China or Serbia, states which had ministries for the diaspora, but no longer do. Sub-ministry level institutions, on the contrary, are present in almost all countries examined, which reflects their concern for having a stable and dedicated institution at the executive level to deal with diaspora issues. Most of these institutions are hierarchically dependent on the Ministry of Foreign Affairs. Yet, the fact that sub-ministerial institutions in Tunisia and Turkey are depending on the Labour and Social Affairs Ministries can be interpreted as a way to dedicate greater focus and expertise to labour migrants and their access to welfare. Lastly, the analysis of interest-representation institutions also produces a mixed picture, as only three states (Ecuador, Tunisia, and Senegal) allow citizens abroad to elect their own members of Parliament. Interestingly, Ecuador and Tunisia introduced such diaspora representation mechanism following regimes changes, therefore indicating how engagement with citizens abroad is reflective of a broader change in the way homeland authorities define their policies. On the contrary, almost all countries in our sample - except for Argentina, Tunisia, and the UK - have an explicit policy and/or institution that allows non-residents to voice their concern to homeland authorities in a non-binding manner (e.g. consultative bodies).

Overall, this comparative overview thus reveals interesting variations in the level of institutionalization of diaspora relations across non-EU states. Ecuador and Senegal have developed the most extensive institutional network for their diaspora but, as discussed in the country chapters, only Ecuador has accompanied these institutions with actual social protection policies for citizens abroad. Furthermore, the Senegalese case is particularly interesting as although the Senegalese diaspora is not very sizeable, it nonetheless has a strong economic leverage due to the high share of remittances from abroad. This trend confirms, as also suggested in past studies on diaspora institutions (Gamlen 2019), that creating such institutions may serve as a tool to signal to the diaspora that their homeland cares about them. A purely symbolic approach to diaspora institutions can therefore reflect the authorities' attempt to instrumentalize non-resident populations to pursue a specific economic or political agenda. In our sample, such strategic approach is also visible in the case of Lebanon, which created a dedicated ministry for its diaspora, does not grant social benefits to nationals abroad, but still designed policies to attract remittances and diaspora investments back to Lebanon.

\subsection{Structure of the Volume}

The rest of the book includes 26 country chapters, two per each country analyzed. One chapter discusses the conditions of access to welfare for resident nationals, non-resident nationals, and non-national residents, whereas the second one focuses 
on diaspora policies and institutions for nationals abroad. For each country, the first chapter starts by providing readers with a contextualization of each case study in terms of key characteristics of their national welfare systems and migration trajectories. This introductory section is followed by an in-depth analysis of the main eligibility conditions under which individuals can access social benefits across five policy areas: unemployment, health care, old-age pensions, family-related benefits, and guaranteed minimum resources. For each country, the authors discuss how foreigners can access these benefits when compared to their national counterparts, while also explaining which welfare entitlements are made available for citizens living abroad.

The second chapter for each country is designed to complement the first one by focusing on diaspora policies and institutions that these non-EU states have developed for their nationals abroad. The first part of these chapters starts with a brief discussion of the characteristics of the diaspora and its relations with the homeland. They then dedicate more attention to key institutions and policies (outside of social protection policies) that regulate these relations. In the second part, authors first discuss the general framework in which sending states develop social protection policies for citizens abroad (consular policies, bilateral social security agreements, membership in regional organizations, etc.); and proceed with the identification of key policies for this population across several policy areas. The chapters conclude by reiterating key factors that explain the development of each country's diaspora policies and institutions.

Acknowledgements This chapter is part of the project "Migration and Transnational Social Protection in (Post) Crisis Europe (MiTSoPro)" that has received funding from the European Research Council (ERC) under the European Union's 2020 research and innovation programme (Grant agreement No. 680014). In addition to this chapter, readers can find a series of indicators comparing national social protection and diaspora policies across 40 countries on the following website: http://labos.ulg.ac.be/socialprotection/. We wish to thank Angeliki Konstantinidou for her assistance in compiling the international migration data used in this chapter.

\section{References}

Adamson, F. B., \& Tsourapas, G. (2019). The migration state in the global south: Nationalizing, developmental, and neoliberal models of migration management. International Migration Review. https://doi.org/10.1177/0197918319879057.

Agunias, D. R., \& Newland, K. (2012). Developing a road map for engaging diasporas in development: A handbook for policymakers and practitioners in home and host countries. Geneva: International Organization for Migration and Migration Policy Institute.

Ahmadov, A. K., \& Sasse, G. (2016). A voice despite exit: The role of assimilation, emigrant networks, and destination in emigrants' transnational political engagement. Comparative Political Studies, 49(1), 78-114.

Amara, M., \& Ayadi, M. (2013). The local geographies of welfare in Tunisia: Does neighbourhood matter? International Journal of Social Welfare, 22, 90-103. https://doi. org/10.1111/j.1468-2397.2011.00863.x. 
Armingeon, K. (2001). Institutionalising the Swiss welfare state. West European Politics, 24(2), $145-168$.

Aybars, A. I., \& Tsarouhas, D. (2010). Straddling two continents: Social policy and welfare politics in Turkey. Social Policy and Administration, 44, 746-763. https://doi. org/10.1111/j.1467-9515.2010.00741.x.

Barrientos, A. (2009). Labour markets and the (Hyphenated) welfare regime in Latin America. Economy and Society, 38(1), 87-108. https://doi.org/10.1080/03085140802560553.

Bertolini, A., \& Clegg, D. (this volume). Access to social protection by immigrants, emigrants and resident nationals in the UK. In J.-M. Lafleur \& D. Vintila (Eds.), Migration and social protection in Europe and beyond (Volume 3). A focus on non-EU sending states. Cham: Springer.

Blauberger, M., \& Schmidt, S. (2014). Welfare migration? Free movement of EU citizens and access to social benefits. Research and Politics, 1(3), 1-7. https://doi.org/10.1177/2053168014563879.

Boccagni, P. (2011). Migrants' social protection as a transnational process: Public policies and emigrant initiative in the case of Ecuador. International Journal of Social Welfare, 20, 318-325. https://doi.org/10.1111/j.1468-2397.2010.00747.x.

Bonoli, G. (1997). Classifying welfare states: A two-dimension approach. Journal of Social Policy, 26(3), 351-372.

Cammett, M., \& Issar, S. (2010). Bricks and mortar clientelism: Sectarianism and the logics of welfare allocation in Lebanon. World Politics, 62(3), 381-421. https://doi.org/10.1017/ S0043887110000080.

Carmona Barrenechea, V., Messina, G., \& Straschnoy, M. (this volume). Access to social protection by immigrants, emigrants and resident nationals in Argentina. In J.-M. Lafleur \& D. Vintila (Eds.), Migration and social protection in Europe and beyond (Volume 3). A focus on non-EU sending states. Cham: Springer.

Cerami, A. (2009). Welfare state developments in the Russian Federation: Oil-led social policy and 'the Russian miracle'. Social Policy and Administration, 43, 105-120. https://doi. org/10.1111/j.1467-9515.2009.00650.x.

Cheikh, N. B. (2013). L'Extension de la Protection Sociale à l'Économie Informelle à l'Épreuve de la Transition en Tunisie. Centre de Recherches et d'Etudes Sociales. Available at: http:// www.cres.tn/uploads/tx_ssdbiblio/extension_couverture_secteur_informel_01.pdf. Accessed 16th Mar 2020.

Cherti, M., \& Collyer, M. (2015). Immigration and Pensée d'Etat: Moroccan migration policy changes as transformation of 'geopolitical culture'. The Journal of North African Studies, 20(4), 590-604. https://doi.org/10.1080/13629387.2015.1065043.

Collyer, M. (2013). Emigration nations: Policies and ideologies of emigrant engagement. New York: Palgrave.

Cook, L. J. (2000). The Russian welfare state: Obstacles to restructuring. Post-Soviet Affairs, 16(4), 355-378. https://doi.org/10.1080/1060586X.2000.10641491.

Delano, A. (2018). From here and there: Diaspora policies, integration, and social rights beyond borders. Oxford: Oxford University Press.

Dioh, A. (this volume). Access to social protection by immigrants, emigrants and resident nationals in Senegal. In J.-M. Lafleur \& D. Vintila (Eds.), Migration and social protection in Europe and beyond (Volume 3). A focus on non-EU sending states. Cham: Springer.

Esping-Andersen, G. (1990). The three worlds of welfare capitalism. Cambridge: Polity Press.

European Migration Network. (2014). Migrant access to social security and healthcare: Policies and practices. Brussels: European Commission.

Ferrera, M. (1996). The "southern" model of welfare in social Europe. Journal of European Social Policy, 6(1), 17-37.

Franzoni, J. M. (2008). Welfare regimes in Latin America: Capturing constellations of markets, families, and policies. Latin American Politics and Society, 50, 67-100. https://doi. org/10.1111/j.1548-2456.2008.00013.x.

Gallo, G., Tintori, G., \& Zincone, G. (2006). The transnational side effects of the nationality laws in the EU. The Italian Case. Available at: http://www.fieri.it/ktml2/files/uploads/attivita/ papers\%20e\%20tesi/Side\%20effects_Italy_04_04_06.pdf. Accessed 20th Mar 2019. 
Gamlen, A. (2019). Human geopolitics: States, emigrants, and the rise of diaspora institutions. Oxford: Oxford University Press.

Gelb, L., \& Marouani, M. (this volume). Access to social protection by immigrants, emigrants and resident nationals in Tunisia. In J.-M. Lafleur \& D. Vintila (Eds.), Migration and social protection in Europe and beyond (Volume 3). A focus on non-EU sending states. Cham: Springer.

Harrigan, J., \& El-Said, H. (2014). Economic reform, social welfare, and instability: Jordan, Egypt, Morocco and Tunisia 1983-2004. Middle East Journal, 68(1), 99-121.

$\mathrm{He}, \mathrm{A}$. J. (this volume). Access to social protection by immigrants, emigrants and resident nationals in China. In J.-M. Lafleur \& D. Vintila (Eds.), Migration and social protection in Europe and beyond (Volume 3). A focus on non-EU sending states. Cham: Springer.

Jawad, R. (2002). A profile of social welfare in Lebanon: Assessing the implications for social development policy. Global Social Policy, 2(3), 319-342. https://doi.org/10.117 $7 / 14680181020020030501$.

Kramer, D., Thierry, J., \& van Hooren, F. (2018). Responding to free movement: Quarantining mobile union citizens in European welfare states. Journal of European Public Policy, 25(10), 1501-1521. https://doi.org/10.1080/13501763.2018.1488882.

Lafleur, J.-M., \& Sánchez-Domínguez, M. (2015). The political choices of emigrants voting in home country elections: A socio-political analysis of the electoral behaviour of Bolivian external voters. Migration Studies, 3(2), 155-181. https://doi.org/10.1093/migration/mnu030.

Lafleur, J.-M., \& Stanek, M. (2017). Restrictions to social protection by new Southern European migrants in Belgium. In J.-M. Lafleur \& M. Stanek (Eds.), South-North migration of EU citizens in times of crisis (IMISCOE research series, pp. 99-121). https://doi. org/10.1007/978-3-319-39763-4_7.

Lafleur, J.-M., \& Vintila, D. (Eds.). (2020a). Migration and social protection in Europe and beyond (Volume 1). Comparing access to welfare entitlements. Cham: Springer.

Lafleur, J.-M., \& Vintila, D. (Eds.). (2020b). Migration and social protection in Europe and beyond (Volume 2): Comparing consular services and diaspora policies. Cham: Springer.

Lafleur, J.-M., \& Vintila, D. (2020c). Do EU member states care about their diasporas' access to social protection? A comparison of consular and diaspora policies across EU27. In J.-M. Lafleur \& D. Vintila (Eds.), Migration and social protection in Europe and beyond (Volume 2). Comparing consular services and diaspora policies. Cham: Springer.

Lafleur, J.-M., \& Vivas Romero, M. (2018). Combining transnational and intersectional approaches to immigrants' social protection: The case of Andean families' access to health. Comparative Migration Studies, 6(1). https://doi.org/10.1186/s40878-018-0073-7.

London, J. D. (2014). Welfare regimes in China and Vietnam. Journal of Contemporary Asia, 44(1), 84-107. https://doi.org/10.1080/00472336.2013.822988.

Margheritis, A. (this volume). Diaspora policies, consular services and social protection for Argentine citizens abroad. In J.-M. Lafleur \& D. Vintila (Eds.), Migration and social protection in Europe and beyond (Volume 3). A focus on non-EU sending states. Cham: Springer.

Martinsen, D. S. (2005). The Europeanization of welfare-The domestic impact of intra-European social security. Journal of Common Market Studies, 43(5), 1027-1054.

Mencutek, Z. S., \& Baser, B. (2018). Mobilizing diasporas: Insights from Turkey's attempts to reach Turkish citizens abroad. Journal of Balkan and Near Eastern Studies, 20(1), 86-105. https://doi.org/10.1080/19448953.2017.1375269.

Merla, L., \& Baldassar, L. (2011). Transnational caregiving between Australia, Italy and El Salvador: The impact of institutions on the capability to care at a distance. In E. Adis, F. Degravre, P. De-Villota, \& J. Eirksen (Eds.), The role of institutions (pp. 147-162). London: Ashgate.

Mkandawire, T. (2016). Colonial legacies and social welfare regimes in Africa. An empirical exercise (Working Paper 2016/4 for the UNRISD project on politics of domestic resource mobilisation). Available at: http://www.unrisd.org/unrisd/website/document.nsf/ (httpPublications)/600078C0E3 281680C1257FC00032132A?OpenDocument. Accessed 20th Mar 2019. 
Østergaard-Nielsen, E., \& Ciornei, I. (2019). Political parties and the transnational mobilisation of the emigrant vote. West European Politics, 42(3), 618-644. https://doi.org/10.1080/0140238 2.2018.1528105.

Österman, M., Palme, J., \& Ruhs, M. (2019). National institutions and the fiscal impact of EU migrants (Working Paper REMINDER project). Available at: https://www.reminder-project. eu/wp-content/uploads/2019/02/REMINDER-D4.3-Institutions-and-Fiscal-Effects.pdf. Accessed 05th May 2020.

Popova, D. (this volume). Access to social protection by immigrants, emigrants and resident nationals in the Russian Federation. In J.-M. Lafleur \& D. Vintila (Eds.), Migration and social protection in Europe and beyond (Volume 3). A focus on non-EU sending states. Cham: Springer.

Ragazzi, F. (2014). A comparative analysis of diaspora policies. Political Geography, 41, 74-89. https://doi.org/10.1016/j.polgeo.2013.12.004.

Riesco, M. (2009). Latin America: A new developmental welfare state model in the making? International Journal of Social Welfare, 18, S22-S36. https://doi. org/10.1111/j.1468-2397.2009.00643.x.

Rudra, N. (2007). Welfare states in developing countries: Unique or universal? The Journal of Politics, 69(2), 378-396. https://doi.org/10.1111/j.1468-2508.2007.00538.x.

Ruhs, M., \& Palme, J. (2018). Institutional contexts of political conflicts around free movement in the European Union: A theoretical analysis. Journal of European Public Policy, 25(10), 1481-1500. https://doi.org/10.1080/13501763.2018.1488883.

Sabates-Wheeler, R., \& Koettl, J. (2010). Social protection for migrants: The challenges of delivery in the context of changing migration flows. International Social Security Review, 63, 115-144. https://doi.org/10.1111/j.1468-246X.2010.01372.x.

Sainsbury, D. (2012). Welfare states and immigrant rights. The politics of inclusion and exclusion. Oxford: Oxford University Press.

Schmidt, S., Blauberger, M., \& Martinsen, D. S. (2018). Free movement and equal treatment in an unequal union. Journal of European Public Policy, 25(10), 1391-1402. https://doi.org/10.108 0/13501763.2018.1488887.

Stambolieva, M. (2013). Welfare and democratization-Comparing Croatia, Serbia and Macedonia. Social Policy and Administration, 47, 142-160. https://doi.org/10.1111/spol.12012.

Tabar, P., \& Denison, A. (this volume). Diaspora policies, consular services and social protection for Lebanese citizens abroad. In J.-M. Lafleur \& D. Vintila (Eds.), Migration and social protection in Europe and beyond (Volume 3). A focus on non-EU sending states. Cham: Springer.

Tabar, P., Denison, A., \& Alkhomassy, M. (this volume). Access to social protection by immigrants, emigrants and resident nationals in Lebanon. In J.-M. Lafleur \& D. Vintila (Eds.), Migration and social protection in Europe and beyond (Volume 3). A focus on non-EU sending states. Cham: Springer.

Trampusch, C. (2010). The welfare state and trade unions in Switzerland: An historical reconstruction of the shift from a liberal to a post-liberal welfare regime. Journal of European Social Policy, 20(1), 58-73. https://doi.org/10.1177/0958928709352539.

Vintila, D., \& Lafleur, J-M. (2020). Migration and access to welfare benefits in the EU: The interplay between residence and nationality. In J.-M. Lafleur \& D. Vintila (Eds.), Migration and social protection in Europe and beyond (Volume 1). Comparing access to welfare entitlements. Cham: Springer.

Zincone, G. (2006). Familismo Legale. Come (Non) Diventare Italiani. Roma: Editori Laterza. 
Open Access This chapter is licensed under the terms of the Creative Commons Attribution 4.0 International License (http://creativecommons.org/licenses/by/4.0/), which permits use, sharing, adaptation, distribution and reproduction in any medium or format, as long as you give appropriate credit to the original author(s) and the source, provide a link to the Creative Commons license and indicate if changes were made.

The images or other third party material in this chapter are included in the chapter's Creative Commons license, unless indicated otherwise in a credit line to the material. If material is not included in the chapter's Creative Commons license and your intended use is not permitted by statutory regulation or exceeds the permitted use, you will need to obtain permission directly from the copyright holder. 